\title{
Composition and abundance of benthic microalgae from the Estuarine Complex of Paranaguá Bay (southern Brazil) with special emphasis on toxic species
}

\author{
Angel Ramón Moreira-González ${ }^{1,2}$, Marco Colossi Brustolin ${ }^{1,3}$, Luiz Laureno \\ Mafra Junior ${ }^{1 *}$ (10)
}

\author{
1 Universidade Federal do Paraná, Centro de Estudos do Mar (Pontal do Paraná - PR - Brazil) \\ ${ }^{2}$ Centro de Estudios Ambientales de Cienfuegos, CEAC (Cienfuegos - Cienfuegos - Cuba) \\ ${ }^{3}$ The University of Auckland, Institute of Marine Science (Auckland - Auckland - New Zealand) \\ *Corresponding author: luiz.mafra@ufpr.br
}

\begin{abstract}
This study addressed the occurrence and distribution of benthic microalgae, with emphasis on toxic species, on different substrates (macroalgae, seagrass and sediments) along the outer, euhaline zone of the Estuarine Complex of Paranaguá Bay, southern Brazil, from July 2015 to May 2016. Canonical analysis of principal coordinates (CAP) was used to identify the potential environmental drivers of microphytobenthic assemblage structure. A total of 18 potentially toxic benthic microalgae species were reported, including 7 dinoflagellates, 9 cyanobacteria, one diatom and one euglenophyte. The abundance of all potentially toxic microalgae varied consistently along the investigated period. Dinoflagellates dominated the microalgae assemblage in July and September 2015. Mean densities on macrophytes ranged from 33.6 cells $\mathrm{g}^{-1}$ in May 2016 to 775.6 cells $\mathrm{g}^{-1}$ in September 2015, being positively correlated with dissolved nitrogen-nutrients, water transparency, salinity, and chlorophyll-a. Prorocentrum cf. lima was the most frequent and abundant dinoflagellate. Overall, the highest abundance of toxic species occurred in February 2016, when cyanobacterial mats dominated by Lyngbya cf. aestuarii were observed throughout the estuary associated with periods of heavier rainfall and higher turbidity (shallower Secchi depth). At that time, a selected microphytobenthic extract exhibited acute toxicity on nauplii of the brine shrimp Artemia salina in the laboratory.
\end{abstract}

Descriptors: Microphytobenthos community structure, Harmful microalgae, Acute toxicity, Cyanobacterial mats, Toxic dinoflagellates, Subtropical estuary.

\section{INTRODUCTION}

Microphytobenthos (MPB) is represented by phototrophic bacteria (i.e., cyanobacteria) and eukaryotic algae, mainly diatoms and dinoflagellates, inhabiting sediment surface, and constitutes

Submitted on: 12/March/2019

Approved on: 7/October/2019

Editor: Rubens M. Lopes an important component of estuarine ecosystems (Semcheski et al., 2016). These organisms play an active role in the uptake of inorganic and organic nutrients and contribute to the primary productivity of shallow areas as basal components of the food web (Underwood and Kromkamp, 1999; Riekenberg et al., 2017). They produce extracellular polymeric substances (EPS) forming biofilms, which increase sediment stability (Tolhurst et al., 2002). In addition to their functional and trophic importances, both community structure and composition of MPB might exhibit a high degree of patchiness 
(Orvain et al., 2012), contributing to overall diversity and richness of benthic communities. Variations in sediment grain size, tidal height, wave energy and the abundance of grazers can affect microphytobenthic distribution creating areas that can act as either "hotspots" or "coldspots" of productivity, nutrient recycling, and carbon sinking (Brustolin et al., 2014; Riekenberg et al., 2018). Understanding the patterns of spatial distribution and temporal dynamics of MPB is thus pivotal.

Several microalgal species belonging to different taxonomic groups, however, can produce potent toxins and bioactive chemical compounds, negatively affecting marine organisms and human health during events known as harmful algal blooms (HABs). Among them, cyanobacteria and dinoflagellates are the main groups of organisms involved in benthic HABs in shallow aquatic environments (Moestrup et al., 2009). While dinoflagellates comprise the majority of HAB-forming species in the marine environment, most toxic events reported in fresh or brackish-water systems have been associated with cyanobacterial blooms (Hallegraeff et al., 2003; Paerl and Huisman, 2009; Quiblier et al., 2013). In shallow, transitional zones like estuarine deltas and tidal flats, variations in sediment characteristics (e.g., grain size, interstitial nutrient concentrations), as well as environmental gradients in the water column (e.g., salinity, temperature, particulate and dissolved organic matter concentrations), ultimately determine the composition and cell abundance of benthic microalgae, including HABs species (Moncer et al., 2017). The dynamics of bentho-pelagic coupling can thus regulate both bloom initiation and development, and their assessment should be included in monitoring and management programs aiming at mitigating the impacts of benthic HABs in these ecologically and economically important coastal areas.

Among marine dinoflagellates, species belonging to the genus Ostreopsis are known to produce the most potent marine toxins known to date - the palytoxin and its analogues, ovatoxins (Hoppenrath et al., 2014). Species of Gambierdiscus and Fukuyoa, two taxonomically related genera, can also produce potent neurotoxins namely ciguatoxins and maitotoxins. Annually, these toxins are responsible for hundreds of cases of Ciguatera Fish Poisoning
(Lassus et al., 2016), the most frequent seafoodborne disease of nonbacterial origin worldwide. Other benthic dinoflagellates such as Amphidinium, Coolia, Prorocentrum and Vulcanodinium may be less commonly associated with impacts to human and ecosystem health. For instance, some benthic Prorocentrum species produce okadaic acid (OA) and dinophysistoxins (DTX), the causative agents of Diarrheic Shellfish Poisoning (DSP) in humans (Hoppenrath et al., 2013; Nascimento et al., 2016), while some Coolia species have been shown to produce cooliatoxin, a yessotoxin analog with neurotoxic action (Holmes et al., 1995; Wakeman et al., 2015). Finally, dense blooms of epibenthic Vulcanodinium rugosum and Amphidinium spp. may also affect the pelagic compartment of coastal areas. Whereas $V$. rugosum produces the cyclic imines pinnatoxins, which are fast-acting neurotoxins (Hoppenrath et al., 2014), Amphidinium spp. produce a number of bioactive compounds (amphidinols and amphidinolides) with cytotoxic and/or hemolytic activity, and may cause fish mortalities during blooms (e.g. Murray et al., 2015; MoreiraGonzález et al., 2019). Some species of cyanobacteria, in addition, can produce a variety of toxic secondary metabolites (cyanotoxins) with biological effects ranging from hepatotoxicity (microcystins, nodularins) to dermatotoxicity (lyngbyatoxins, aplysiatoxins), cytotoxicity (cylindrospermopsins) and neurotoxicity (anatoxins, saxitoxins) (Pearson et al., 2010; Lopes and Vasconcelos, 2011).

Recent increase in the abundance of benthic toxic microalgae - and its associated deleterious effects to benthic communities - has been linked to climate changes, caused by global warming and anthropogenic activities including the eutrophication of coastal systems and marine habitat destruction (Skinner et al., 2013; Moncer et al., 2017). Blooms of the benthic dinoflagellate Ostreopsis have become more frequent and intense in temperate waters (Berdalet et al., 2017). Moreover, an increase in the abundance of toxic benthic dinoflagellates from the genera Prorocentrum and Ostreopsis has been consistently observed in coral reef communities experiencing a decrease in coral abundance due to eutrophication and acidification, for instance (Skinner et al., 2013). Coastal environments are thus facing an additional threat as benthic HABs 
become more frequent, severe and spread over a broader geographic distribution, including temperate and subtropical areas.

The subtropical Estuarine Complex of Paranaguá Bay $(E C P B)$ is one of the largest estuarine systems in Brazil. This estuary provides food and nursery to a great variety of marine life including economically important species of shrimp, crabs and fish, as well as species facing anthropogenic threats such as the "near threatened" Guiana dolphin (Sotalia guianensis) and the "endangered" green seaturtle (Chelonia mydas) (Lana et al., 2001). To date, ecological studies on harmful microalgae have been majorly focused on planktic species in the ECPB (e.g. Mafra Júnior et al., 2006, 2014), so that the environmental and health risks associated with toxic benthic microalgae and cyanobacteria are largely neglected. Therefore, the main purpose of this study is to determine the temporal variation, from July 2015 to May 2016, in the composition and abundance of benthic microalgae - with emphasis on toxic species - growing on different substrates in the outer portion of the ECPB. The potential threats of toxic benthic microalgae to marine organisms and human health are evaluated.

\section{MATERIALS AND METHODS}

\section{STUDY AREA}

The ECPB is a tide-dominated estuarine system of the subtropical, southern Brazilian coast $\left(25^{\circ} 30^{\prime} \mathrm{S}\right.$, $48^{\circ} 30^{\prime} \mathrm{W}$; Figure 1), influenced by a mesothermic humid climate ( $\sim 85 \%$ mean air humidity) (Lana et al., 2001). It is formed by four interconnected water bodies. While the Paranaguá and Antonina bays occupy $260 \mathrm{~km}^{2}$ along the east-west axis, the Laranjeiras and Pinheiros bays occupy $200 \mathrm{~km}^{2}$ along the south-north axis. The area is composed of a rich mosaic of nearly pristine habitats including mangroves swamps, salt marshes and extensive sandmuddy tidal flats. The environment can be divided into distinct sectors according to the salinity range: oligo- to mesohaline (inner), polyhaline (intermediate), and euhaline (outer) sectors (Lana et al., 2001). The mouth of the estuary is $>10 \mathrm{~m}$ deep and the bottom sediments are characterized by well-sorted fine to very fine sediments (grain size $<0.062 \mathrm{~mm}$ ). The intermediate zone, also influenced by marine waters, represents the widest cross-section of the

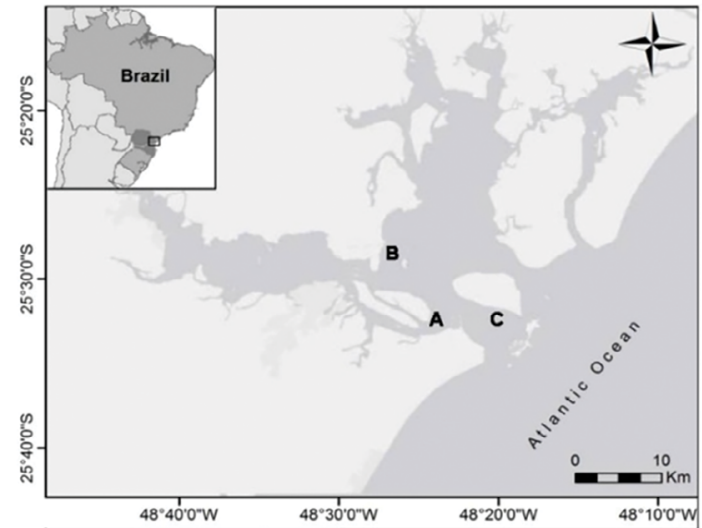

Figure 1. Map of the study area and sampling sites along the Estuarine Complex of Paranaguá Bay, southern Brazil.

estuary, with depths ranging from 4 to $10 \mathrm{~m}$ and the bottom mainly characterized by muddy sediments (Marone et al., 2005; Mizerkowski et al., 2012).

Weather conditions can vary according to two main climate seasons: dry (April-September), with mean salinity of 20-34 and water temperature of $18-25{ }^{\circ} \mathrm{C}$, and rainy season (October-March), with mean salinity of 12-29 and water temperature of 23-30 ${ }^{\circ} \mathrm{C}$. Mean annual precipitation is $3000 \mathrm{~mm}$ (Mizerkowski et al., 2012). Freshwater input varies from $30 \%$ up to $170 \%$ of the annual mean during, respectively, the dry season and rainy seasons. Yet the annual precipitation does not exhibit a very pronounced dry-winter period like other humid subtropical areas around the world. The local hydrodynamics is controlled by a semidiurnal tidal range up to $2.2 \mathrm{~m}$. The system is partially mixed, with a residence time of 3.5 days and a mean freshwater runoff of up to $200 \mathrm{~m}^{3} \mathrm{~s}^{-1}$ (Lana et al., 2001; Marone et al., 2005).

\section{SAMPLING DeSign AND SAMPLE COLLeCtion}

Sampling campaigns were performed approximately every three months, on July 1-2 (early austral winter) and September 23-24 of 2015 (early spring), and on February 23-24 (summer) and May 19-20 of 2016 (autumn). Three sampling sites were located at the outer (euhaline) sector of the ECPB: site A $\left(25^{\circ} 32^{\prime} \mathrm{S}, 48^{\circ} 24^{\prime} \mathrm{W}\right), \mathrm{B}\left(25^{\circ} 28^{\prime} \mathrm{S}, 48^{\circ} 27^{\prime} \mathrm{W}\right)$ and $\mathrm{C}\left(25^{\circ} 31^{\prime} \mathrm{S}, 48^{\circ} 19^{\prime} \mathrm{W}\right)$, with the latter closer to the mouth of the estuary (Figure 1).

In each sampling site, benthic microalgae were collected on three different substrates: bare sand 
and two dominant macrophytes. This way, the entire diversity of microphytobenthic assemblage could be assessed, including epipelic and epipsammic algal species inhabiting intertidal sediments, as well as epiphytic species associated with macrophytes. It was not possible to sample the same species of macrophyte at all occasions as their availability varied geographically and temporally throughout the studied period. The dominant macrophytes were mainly opportunistic chlorophycean algae such as Ulva and Chaetomorpha spp., while less frequent macrophytes included red seaweed members of the genera Acanthophora and Hypnea, as well as the seagrass Halodule wrightii. More specifically, macrophyte samples were composed of Ulva lactuca, $U$. flexuosa, Ulva sp. and Hypnea spinella in July 2015; U. lactuca, Ulva sp., Acanthophora spicifera, Hypnea musciformis and the seagrass Halodule wrightii in September 2015; U. lactuca, Ulva sp., Chaetomorpha sp., and Lyngbya cf. aestuarii in February 2016; and U. lactuca, Ulva sp., Chaetomorpha sp., A. spicifera and $H$. wrightii in May 2016. In all campaings, six replicated samples were collected per substrate in each sampling site, representing 18 samples per site per month (216 samples in total).

Macrophytes samples of 5-16g wet weight were collected manually during low spring tide (about 0.1 to $0.3 \mathrm{~m}$ deep), and placed into plastic bags containing $200 \mathrm{~mL}$ of $0.22 \mu \mathrm{m}$ filtered seawater (FSW). In addition, a $2.5 \mathrm{~cm}$ (diameter) corer was used to sample $1 \mathrm{~cm}$ layers of superficial sediment, which were transferred to plastic bags as previously described. One extra sub-sample of sediment was collected from each site for determination of chlorophyll- $a$ and pheophytin concentrations, and for granulometric analysis.

At each site, water samples were simultaneously collected from adjacent waters at $0.5 \mathrm{~m}$ from the surface (sub-surface) and $0.5 \mathrm{~m}$ from the bottom (mean depth $\sim 3 \mathrm{~m}$ ) with a Van Dorn water sampler for nutrient analysis. Temperature and salinity were measured in situ with a calibrated COMPAC CTD profiler (JFE Advantech Co., Ltd.). Water transparency was estimated from a Secchi disk. Dailyaveraged relative humidity, solar radiation, wind speed, and accumulated rainfall from the 15 days preceding each sampling campaign were obtained from a semi-automatic meteorological station located near the ECPB, whose data were made available by the Brazilian National Meteorology Institute (INMET).

\section{LABORATORY ANALYSES}

Plastic bags containing water and macrophytes (or sediment) were vigorously shaken to detach microalgal cells from the substrate. The suspension was then passed through a 300 $\mu \mathrm{m}$ Nitex mesh to eliminate larger particles, collected into amber glass flasks and preserved with Lugol's solution at $1 \%$ (final concentration).

Sample aliquots were observed prior to preservation for taxonomic identification. Both living and Lugol-preserved cells were photographed on an Olympus ${ }^{\circ}$ BX-41 microscope using a Canon ELH 135 digital camera, under $400 \times$ and $1000 \times$ magnifications. Microalgal species were identified following Hallegraeff et al. (2003), Crispino and Sant'Anna (2006), Hoppenrath et al. (2014) and Lassus et al. (2016). Prior to cell enumeration all samples were manually homogenized for $1 \mathrm{~min}$ in order to remove excess sediment and, thereafter, $70 \mathrm{~mL}$ aliquots of each preserved sample were dispensed into a $24 \times 2 \mathrm{~cm}$ (height $\times$ diameter) glass tube. After allowing settlement of the larger sediment particles for $3 \mathrm{~min}, 1 \mathrm{~mL}$ of each sample was drawn from the tube with a Pasteur pipette at $5 \mathrm{~cm}$ depth (Brustolin et al., 2016), and microalgal cell numbers were counted under 200x magnification using a Sedgewick-Rafter counting slide. The most abundant taxa, including non-toxic diatoms and selected cyanobacterium species collected in February 2016, were only counted in transects equivalent to $150 \mu \mathrm{l}$ of sample, which usually contained $>300$ cells of each taxon. In the case of free trichome-forming cyanobacteria, the average number of cells containing in $25 \mu \mathrm{m}$ long portions of the filaments was recorded ( $n=80$ portions), and the total number of cells estimated by taking the number and length of trichomes into account. Fresh weight of each macrophyte was measured using a balance (Shimadzu', model AY220) and the abundance of cells was then expressed as cells $\mathrm{g}^{-1}$ (wet weight) of macrophyte, or as cells $\mathrm{cm}^{-2}$ in the case of sediment samples, and posteriorly converted to relative (i.e. percent) abundances to allow comparison across different types of substrates. 
Prior to nutrient analysis, seawater samples were filtered through Whatman-GF/C filters $(45 \mathrm{~mm}$ diameter, $0.8 \mu \mathrm{m}$ nominal pore size), which were stored at $-18{ }^{\circ} \mathrm{C}$ until further treatment. The concentration of dissolved inorganic nutrients (Phosphate- $\mathrm{PO}_{4}{ }^{3-}$, Ammonium- $\mathrm{NH}_{4}{ }^{+}$, Nitrate- $\mathrm{NO}_{3}{ }^{-}$and Nitrite- $\mathrm{NO}_{2}{ }^{-}$) was determined by spectrophotometric methods. Nitrate and nitrite concentrations were analyzed following the diazotization reaction; phosphate after the phosphorus blue reactions; and ammonium levels following the indophenol blue method (Grasshoff et al., 1983). Sediment samples for grain size determination were dried and treated with $10 \%$ hydrogen peroxide to digest the organic matter. Then, samples were dried again and weighed to obtain the total dry weight. Each grain size fraction ( $\geq 500 ; 250-499 ; 125-$ $249 ; 63-124$; and $\leq 63 \mu \mathrm{m}$, or mud) was sieved, individually weighed, and expressed as a percentage of the total dry weight. The statistical parameters obtained from the granulometric analyses were calculated with the SysGran 3.0 software (Camargo, 2006).

\section{ARTEMia salina SURVIVAL TEST With a Microphytoben-} THIC EXTRACT

Cyanobacterial mats, composed predominantly of Lyngbya cf. aestuarii, were manually collected at site A in February 2016. Prior to the preparation of the extract, a $5 \mathrm{~mL}$ aliquot of the cyanobacterial mat sample was taken and stored in iodine Lugol solution (1\%) for further counting of MPB cells. Then, approximately $5-10 \mathrm{~g}$ of $L$. cf. aestuarii-dominated mats were disrupted using a sonic dismembrator (130W; Cole Parmer CPX130, USA) for 2 min at $50 \%$ duty cycle, to release the cellular content. An aliquot of the extract was observed under the microscope to assure complete cell disruption. The sonicated extract was then diluted 8 times and filtered onto Millipore $0.22 \mu \mathrm{m}$ pore syringe filters to remove cell debris. Due to dilution before filtration, the maximum concentration tested was equivalent to $12.5 \%$ of the original homogenate. Successive dilutions were prepared in FSW and six concentrations corresponding to decreasing cell densities of Lyngbya were thus tested: $12.5 \%$ (1980 cell-eq. $\mathrm{mL}^{-1}$ ), $6.25 \%$ (990 cell-eq. $\mathrm{mL}^{-1}$ ), 3.12\% (495 cell-eq. $\mathrm{mL}^{-1}$ ), $1.56 \%$ (248 cell-eq. $\mathrm{mL}^{-1}$ ), $0.78 \%$ (124 cell-eq. $\mathrm{mL}^{-1}$ ) and $0.33 \%$ (62 cell-eq. $\mathrm{mL}^{-1}$ ), in addition to a control treatment (FSW only). For each treatment tested, $4.5 \mathrm{~mL}$ of the solution were placed into wells of 6-well culture plates, in triplicate. Ten $( \pm 2.8$, standard deviation) 5 -day-old Artemia salina larvae, previously ecloded from cysts under light and gentle aeration, were placed into each well. Survival was checked after $48 \mathrm{~h}$ of exposure at $25{ }^{\circ} \mathrm{C}$ in darkness. Larvae were considered dead only when no internal or external movement was observed under a stereoscope during 30 s. The toxicity results were expressed as the equivalent abundance of cyanobacteria (cell-eq. $\mathrm{mL}^{-1}$ ) causing $50 \%$ of mortality $\left(L C_{50}\right)$. The non-observed-effect concentration (NOEC) and the lowest-observed-effect concentration $(L O E C)$ were also determined.

\section{DatA ANALYSIS}

Before averaging the values for each sampling month, and prior to the statistical analysis, zero values were attributed whenever a given microalgal species exhibited cell abundance below the detection limit of the counting method (i.e., 13 cells $\mathrm{cm}^{-2}$ or 4-13 cells $\mathrm{g}^{-1}$, depending on the weight of macrophytes sampled). In order to visualize the spatial structure of both overall and potentially toxic microphytobenthic assemblages over four different months, non-metric multi-dimensional scaling (n-MDS) (Anderson and Willis, 2003) analyses based on the Bray-Curtis dissimilarity matrices were carried out. To evaluate the significance of differences between groups of samples observed in nMDSs, permutational multivariate analyses of variance (PERMANOVA, Anderson, 2001) based on the Bray-Curtis dissimilarity matrices were performed. Because of the restricted number of possible permutations in pairwise tests, $p$-values were obtained from Monte Carlo samplings based on 999 permutations (Anderson and Robinson, 2003).

Canonical analysis of principal coordinates (CAP) was further performed to identify possible correlations between the environmental variables and either toxic microalgae or the overall microphytobenthic assemblage. Environmental variables were standardized ( $z$-scores) and microalgal relative abundances were transformed using the arcsine square root. ANOVAs were then performed to evaluate the significance of the canonical axes. All analyses were performed in $\mathrm{R}$ environment using the 'vegan' package (Oksanen et al., 2016). 


\section{RESULTS}

\section{ENVIRONMENTAL VARIABLES}

The average grain size ranged from $156 \mu \mathrm{m}$ in May to $199 \mu \mathrm{m}$ in July (Table 1), whereas average organic matter contents varied from $1.12 \%$ in July to $3.13 \%$ in May. Carbonate content varied between $0.99 \%$ in July and $3.94 \%$ in May. There was no clear temporal pattern for the variation of chlorophyll- $a$ concentrations in the sediment over the studied period, with mean values ranging from $7.60 \mu \mathrm{g} \mathrm{mm}$ ${ }^{3}$ in May to $13.0 \mu \mathrm{g} \mathrm{mm}^{-3}$ in July (Table 1 ).

Seawater temperature ranged from $20.9^{\circ} \mathrm{C}$ in July to $28.1{ }^{\circ} \mathrm{C}$ in February, whereas the highest averaged salinity value (32.0) was recorded in May and the lowest (23.7) in February. Secchi disk transparency varied from $1.20 \mathrm{~m}$ in February and May to $1.70 \mathrm{~m}$ in July (Table 1). The highest averaged ammonium $\left(13.2 \mu \mathrm{mol} \mathrm{L}^{-1}\right)$ concentration was recorded in September and the lowest $\left(10.5 \mu \mathrm{mol} \mathrm{L}^{-1}\right)$ in May. Average nitrate and nitrite concentrations varied from $0.94 \mu \mathrm{mol} \mathrm{L}^{-1}$ in February to $2.36 \mu \mathrm{mol} \mathrm{L}^{-1}$ in July, and from $0.18 \mu \mathrm{mol} \mathrm{\textrm {L } ^ { - 1 }}$ in September to $1.02 \mu \mathrm{mol}$ $\mathrm{L}^{-1}$ in May, respectively. Phosphate levels concentrations, on average, ranged from $0.07 \mu \mathrm{mol} \mathrm{L}^{-1}$ in February to $0.31 \mu \mathrm{mol} \mathrm{L}^{-1}$ in September (Figure 2).

Table 1. Mean values of physical-chemical parameters measured in the seawater and sediment from the ECPB during the period of July 2015 to May 2016: water temperature (T); salinity (Sal); Secchi transparency (SD); chlorophyll- $a$ concentration (Chl. $a$ ); mean grain size (Grain S.); organic matter content (OMC); and calcium carbonate content $\left(\mathrm{CaCO}_{3}\right)$.

\begin{tabular}{lcccc}
\hline & $\begin{array}{c}\text { July } \\
\mathbf{2 0 1 5}\end{array}$ & $\begin{array}{c}\text { Sept. } \\
\mathbf{2 0 1 5}\end{array}$ & $\begin{array}{c}\text { Feb. } \\
\mathbf{2 0 1 6}\end{array}$ & $\begin{array}{c}\text { May } \\
\mathbf{2 0 1 6}\end{array}$ \\
\hline Water column & & & & \\
$\mathrm{T}\left({ }^{\circ} \mathrm{C}\right)$ & 20.9 & 24.8 & 28.1 & 21.6 \\
Sal & 30.5 & 31.5 & 23.7 & 32.0 \\
$\mathrm{SD}(\mathrm{m})$ & 1.70 & 1.30 & 1.20 & 1.20 \\
Sediment & & & & \\
Chl. $a\left(\mu \mathrm{g} \mathrm{mm}{ }^{-3}\right)$ & 13.0 & 12.5 & 11.6 & 7.60 \\
Grain S. $(\mu \mathrm{m})$ & 199 & 172 & 173 & 156 \\
$\mathrm{OMC} \%)$ & 1.12 & 1.31 & 1.59 & 3.13 \\
$\mathrm{CaCO}_{3}(\%)$ & 0.99 & 2.26 & 2.35 & 3.94 \\
\hline
\end{tabular}

Among the relevant meteorological variables, solar radiation - measured as the average value over the 15 days preceding the sampling date was always greater than $300 \mathrm{MJ} \mathrm{m}^{-2} \mathrm{~d}^{-1}$, with the minimum value (360MJ $\mathrm{m}^{-2} \mathrm{~d}^{-1}$ ) recorded in July and the maximum $\left(891 \mathrm{MJ} \mathrm{m}^{-2} \mathrm{~d}^{-1}\right)$ in February. The highest averaged wind speeds were $2.64 \mathrm{~m} \mathrm{~s}^{-1}$ in February and $2.53 \mathrm{~m} \mathrm{~s}^{-1}$ in September, whereas the lowest value $\left(2.08 \mathrm{~m} \mathrm{~s}^{-1}\right)$ was recorded in July (Table 2). Furthermore, relative air humidity and precipitation followed the typical characteristics of a humid subtropical ecosystem, with high relative humidity throughout the year and intense rainfall during the rainy-summer period (here represented by February sampling campaing). The highest $15 \mathrm{~d}$ accumulated precipitation was $339 \mathrm{~mm}$, recorded in February, and the lowest was $20.0 \mathrm{~mm}$, registered in July (Table 2).

TEMPORAL VARIATION OF THE MICROPHYTOBENTHIC ASSEMBLAGE WITH EMPHASIS ON TOXIC SPECIES

The MPB was dominated by non-toxic diatoms, both in terms of richness and cell density (>90\% of the total abundance) (Figure 3 and Appendix A). The most frequent and abundant were the pennate species belonging to the Pleurosigma/ Gyrosigma complex. Among the centric diatoms, the marine tychoplanktic Paralia sulcata was the most common species. Less abundant components of the microphytobenthic community included the euglenophyte Euglenaformis proxima and nontoxic benthic dinoflagellates such as Amphidinium bipes, Amphidiniopsis sp., Ankistrodinium semilunatum, Sinophysis sp. and Prorocentrum cf. fukuyoi (Appendix A). Within each of the major groups of benthic microalgae, cell abundance of cyanobacteria was markedly higher in February, while euglenophytes were more abundant in May, and dinoflagellates in July and September, relative to the other months. Diatoms were slightly less abundant in September (Figure 3 and Appendix A), but always dominant compared to other algal groups.

Eighteen potentially toxic species of microalgae were found within the MPB assemblage, including nine species of cyanobacteria, seven of dinoflagellates, one diatom (Pseudo-nitzschia sp.) and one 

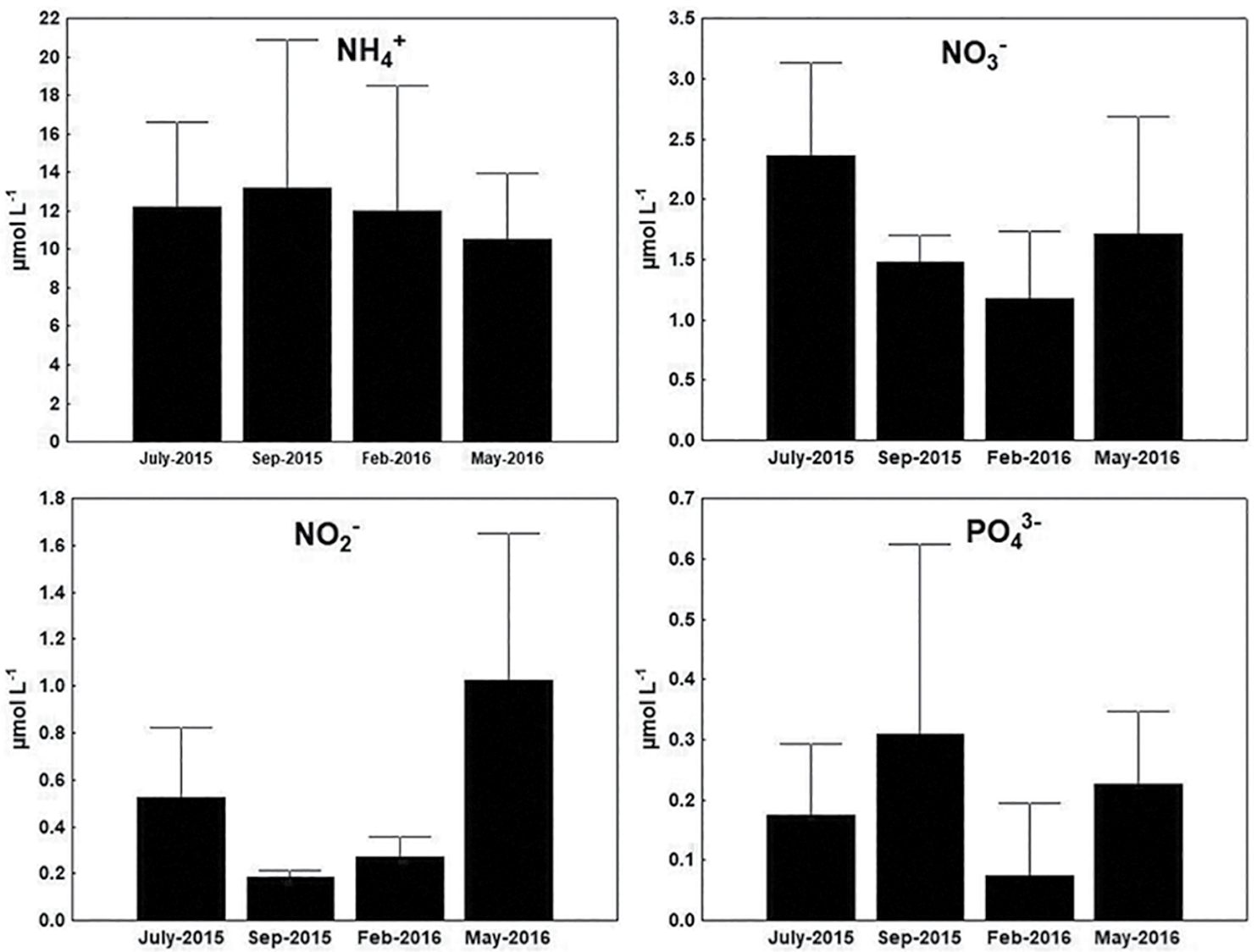

Figure 2. Dissolved nutrient concentrations measured along the Estuarine Complex of Paranaguá Bay, southern Brazil.

Table 2. Meteorological variables measured in the study area. Mean values calculated from the records of 15 days preceding the sampling date (accumulated values in the case of rainfall).

\begin{tabular}{lcccc}
\hline & $\begin{array}{c}\text { July } \\
\mathbf{2 0 1 5}\end{array}$ & $\begin{array}{c}\text { Sept. } \\
\mathbf{2 0 1 5}\end{array}$ & $\begin{array}{c}\text { Feb. } \\
\mathbf{2 0 1 6}\end{array}$ & $\begin{array}{c}\text { May } \\
\mathbf{2 0 1 6}\end{array}$ \\
\hline Rainfall $(\mathrm{mm})$ & 20.0 & 54.2 & 339 & 49.2 \\
Humidity (\%) & 84.9 & 85.9 & 84.3 & 85.1 \\
Wind speed $\left(\mathrm{m} \mathrm{s}^{-1}\right)$ & 2.08 & 2.53 & 2.64 & 2.18 \\
$\begin{array}{l}\text { Solar radiation (MJ } \\
\left.\mathrm{m}^{-2} \text { day }^{-1}\right)\end{array}$ & 360 & 636 & 891 & 764 \\
\hline
\end{tabular}

euglenophyte (Euglenaria clavata) (Appendix A). Potentially toxic cyanobacteria were represented by seven genera (Anabaena, Calothrix, Chroococcus, Coelosphaerium, Lyngbya, Merismopedia, Oscillatoria and Phormidium); whereas dinoflagellates were represented by four genera (Amphidinium, Coolia, Dinophysis and Prorocentrum) (Figures 4 and Appendix A). Fourteen of the potentially toxic species were typically benthic, while other four were planktic species eventually found on the sediment and macrophytes, including the dinoflagellates Dinophysis cf. acuminata and Prorocentrum minimum, the diatom Pseudo-nitzschia sp., and the cyanobacteria Coelosphaerium sp. (Appendix A). These were included in our analysis assuming that they would be readily available to the benthic food web. Nevertheless, typical benthic species were always dominant, contributing with $79.5 \%$ (July in station C) to $99.8 \%$ (February in station A) of the total number of potentially toxic microalgal cells living in close association with the substrate.

The structure of the microphytobenthic assemblage - both for overall MPB and potentially toxic microalgae - varied significantly over time and between the two types of substrate during the investigated period ( $p=0.001$ in all cases). In addition, in both cases, there were significant interactions between the substrate type and time $(p=0.001)$, 

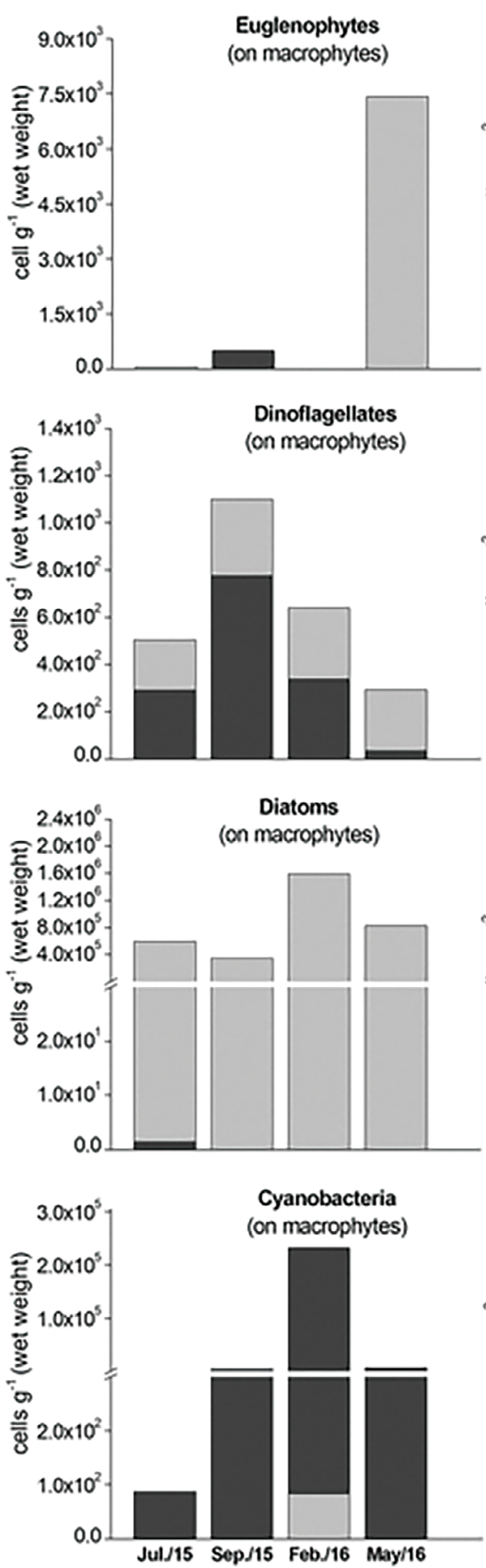
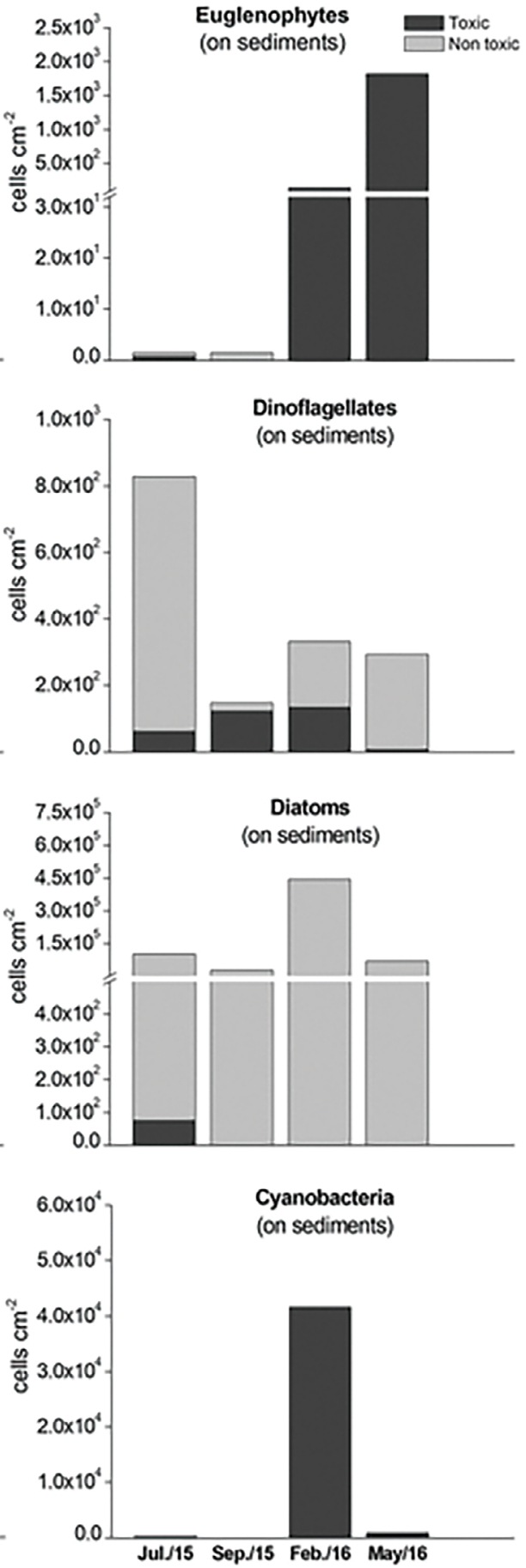

Figure 3. Temporal variation of the cell abundance among the main groups of benthic microalgae collected on different substrates in the ECPB from July 2015 to May 2016. Note different $y$-axis scales. 


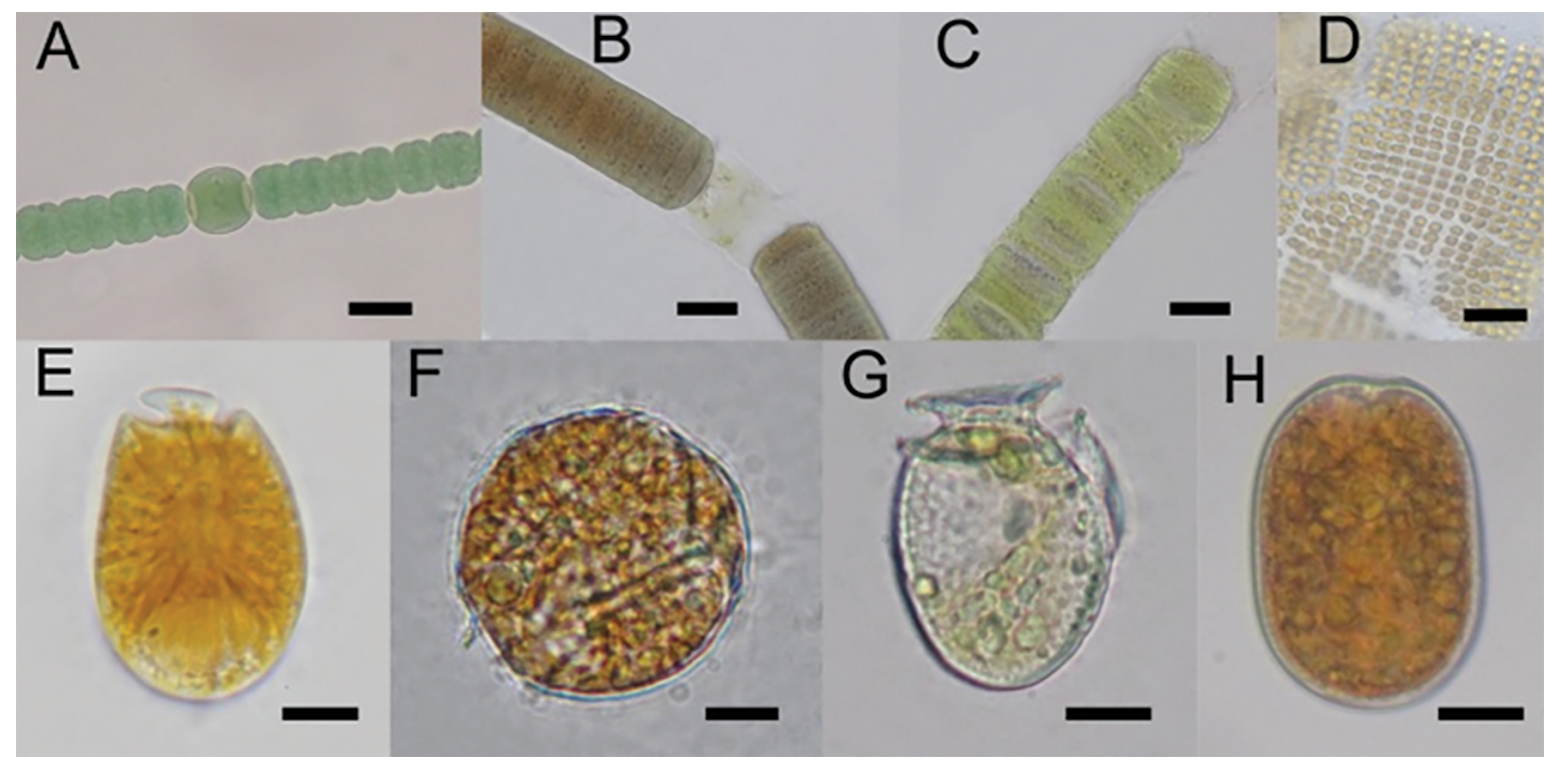

Figure 4. Light-microscopy photomicrographs of some distinctive potentially toxic microalgal species found in the study area: (A) Anabaena sp.; (B-C) Lyngbya cf. aestuarii; (B) Vegetative trichome; (C) Reproduction of short trichome, showing the formation of hormogonia by cell division; (D) Merismopedia elegans; (E) Amphidinium operculatum; (F) Coolia malayensis; (G) Dinophysis cf. acuminata; (H) Prorocentrum cf. lima. Scale bars; (A-C): $5 \mu \mathrm{m} ;(\mathrm{D}-\mathrm{H}): 10 \mu \mathrm{m}$.

suggesting that the dissimilarity observed in assemblage structure over time is dependent on the substrate type (Figure 3 and Table 3). Among the potentially toxic species, cyanobacteria exhibited the highest cell densities, followed by euglenophytes and dinoflagellates (Figure 5).

Considering all macrophyte samples, cell abundance of potentially toxic cyanobacteria ranged from undetectable levels to $1,456,500$ cells $\mathrm{g}^{-1}$ (monthly average during the studied period: 60,300 cells $\mathrm{g}^{-1}$ ), and represented, on average, $99.4 \%$ of the total cell abundance of potentially toxic microalgae and $6.6 \%$ of the total benthic microalgal community. Maximum cell densities were registered in February (average: 231,600 cells $\mathrm{g}^{-1}$ ). The other groups were much less abundant. Cell density of potentially toxic dinoflagellates, for instance, ranged from undetected to 5200 cells g $^{-1}$ (monthly average: 360 cells g$^{-1}$ ), with maximums in September (average: 780 cells $\mathrm{g}^{-1}$ ). They represented $0.6 \%$ of the total cell density of potentially toxic microalgae and only $0.04 \%$ of the total benthic microalgal community. For potentially toxic euglenophytes, cell abundance ranged from undetected to 21,900 cells $\mathrm{g}^{-1}$ (montlhy average: 1900 cells $\mathrm{g}^{-1}$ ), with higher values registered in May (average: 4900 cells $\mathrm{g}^{-1}$ ). Finally, the potentially toxic diatom Pseudo-nitzschia sp. was detected only in July and at very low cell abundance (maximum 52 cells $\mathrm{g}^{-1}$; Appendix $\mathrm{A}$ ).

A peak in the abundance of potentially toxic benthic microalgae was observed in February, when blooms of cyanobacteria occurred (Figure 3). The cyanobacteria $L$. cf. aestuarii was the dominant species at that time with an average cell density of 51,500 cells $\mathrm{g}^{-1}$, accounting for $80.5 \%$ of the toxic microalgal abundance and $9.8 \%$ of the overall abundance in MPB. Widespread, short mats of cyanobacteria, dominated by $L$. cf. aestuarii, were observed in this area of the estuary. Other relatively abundant cyanobacterial species, such as Anabaena sp., Merismopedia elegans and Phormidium spp., represented $10.8 \%$, $1.7 \%$ and $1.6 \%$ of the toxic microalgal abundance in summer, respectively (Figure 5 and Appendix A). In turn, the potentially toxic dinoflagellates were dominant in July and September. The highest density of Prorocentrum cf. lima, the most frequent and abundant species among toxic dinoflagellates, was

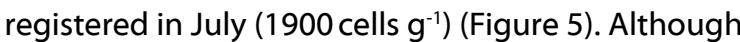
the maximum abundance of dinoflagellates has occurred in July, accounting for $78.1 \%$ of contribution to the total abundance of potentially toxic benthic microalgae, their relative contribution to the total abundance of microphytobenthos was very limited $(0.09 \%)$ at that time (Figure 3$)$. Moreover, toxic 
Table 3. Permutational multivariate analysis of variance (PERMANOVA) of the microphytobenthic assemblage, and potentially toxic microalgae among substrates and sampling months.

\begin{tabular}{|c|c|c|c|c|c|c|c|c|}
\hline \multicolumn{5}{|c|}{ Microphytobenthic assemblage } & \multicolumn{4}{|c|}{ Toxic microalgae } \\
\hline & $d f$ & ss & Pseudo-F & p (perm) & $d f$ & SS & Pseudo-F & $\mathbf{p}$ (perm) \\
\hline Time & 3 & $1.883 \mathrm{e} 5$ & 22.922 & 0.001 & 3 & $1.515 \mathrm{e}^{5}$ & 19.444 & 0.001 \\
\hline Substrate & 1 & 30303 & 11.065 & 0.001 & 1 & 35953 & 13.834 & 0.001 \\
\hline $\operatorname{Tm} \times \mathrm{Sb}$ & 3 & 80867 & 9.842 & 0.001 & 3 & 29618 & 11.397 & 0.001 \\
\hline Res & 208 & $5.696 \mathrm{e}^{5}$ & - & & 208 & $5.405 \mathrm{e}^{5}$ & - & \\
\hline Total & 215 & $8.818 \mathrm{e}^{5}$ & - & & 215 & $8.413 e^{5}$ & - & \\
\hline \multirow[t]{12}{*}{ Pair-wise } & \multicolumn{4}{|c|}{ July 2015} & \multicolumn{4}{|c|}{ July 2015} \\
\hline & Stations & $\mathrm{t}$ & $p($ perm $)$ & $\mathrm{p}(\mathrm{MC})$ & Stations & $\mathrm{t}$ & $p($ perm) & $\mathrm{p}(\mathrm{MC})$ \\
\hline & sed-mac & 2.264 & 0.004 & 0.004 & sed-mac & 1.897 & 0.002 & 0.004 \\
\hline & \multicolumn{4}{|c|}{ Sept. 2015} & \multicolumn{4}{|c|}{ Sept. 2015} \\
\hline & Stations & $\mathrm{T}$ & $p$ (perm) & $p(M C)$ & Stations & $\mathrm{t}$ & $p$ (perm) & $p(M C)$ \\
\hline & sed-mac & 3.158 & 0.001 & 0.001 & sed-mac & 3.179 & 0.001 & 0.001 \\
\hline & \multicolumn{4}{|c|}{ Feb. 2016} & \multicolumn{4}{|c|}{ Feb. 2016} \\
\hline & Stations & $\mathrm{t}$ & $p($ perm $)$ & $\mathrm{p}(\mathrm{MC})$ & Stations & $\mathrm{t}$ & $p($ perm $)$ & $p(M C)$ \\
\hline & sed-mac & 4.572 & 0.001 & 0.001 & sed-mac & 4.547 & 0.001 & 0.001 \\
\hline & \multicolumn{4}{|c|}{ May 2016} & \multicolumn{4}{|c|}{ May 2016} \\
\hline & Stations & $t$ & $p$ (perm) & $p(M C)$ & Stations & $\mathrm{t}$ & $p($ perm) & $\mathrm{p}(\mathrm{MC})$ \\
\hline & sed-mac & 3.216 & 0.001 & 0.001 & sed-mac & 4.712 & 0.001 & 0.001 \\
\hline
\end{tabular}

dinoflagellates and cyanobacteria had a higher contribution to overall cell abundances in macrophyte relative to sediment samples (Figure 3 ).

As revealed by CAP analysis, the abundance of $L$. cf. aestuarii and other dominant cyanobacteria was strongly associated with higher rainfall in summer. Likewise, cell density of dominant dinoflagellates, including toxic species (e.g., A. operculatum and $P$. cf. lima), exhibited a moderate, positive correlation with water transparency and salinity. In both cases, CAP explained a significant amount of variation in assemblage structure $\left(R^{2}=50.9 \%\right.$ and $R^{2}=43.2 \%$ for overall MPB and potentially toxic microalgae, respectively) (Figures 6 and 7). In addition, a few species among the dominant potentially toxic MPB exhibited some degree of substrate preference. The cyanobacteria $L$. cf. aestuarii as well as the dinoflagellates $A$. operculatum and $P$. cf. lima were relatively more abundant on macrophytes than sediments, while Phormidium sp., in contrast, was generally more abundant on sediments, except in September (Figure 5).
ACUTE TOXICITY OF A MICROPHYTOBENTHIC EXTRACT TO ARTEMIA SALINA LARVAE

The extract of Lyngbya cf. aestuarii-dominated mats was acutely toxic to Artemia salina larvae, with a median lethal concentration $\left(L C_{50}\right)$ equivalent to 830 cells $\mathrm{mL}^{-1}$ after $48 \mathrm{~h}$ of exposure. At that time, the lowest-observed-effect concentration (LOEC) was equivalent to 62 cells $\mathrm{mL}^{-1}$, which corresponded to the lowest exposure level tested in this bioassay.

\section{DISCUSSION}

This study reported the occurrence of potentially toxic benthic microalgae in the Estuarine Complex of Paranaguá Bay (ECPB), southern Brazil, associated with different substrates such as green algae, red seaweed, seagrass and fine sediment. However, microphytobenthos (MPB) was largely dominated - in terms of richness and abundance - by non-toxic pennate diatoms, as previously reported in the ECPB (Fonseca et al., 2013) and in other estuaries worldwide (Semcheski et al., 2016). 

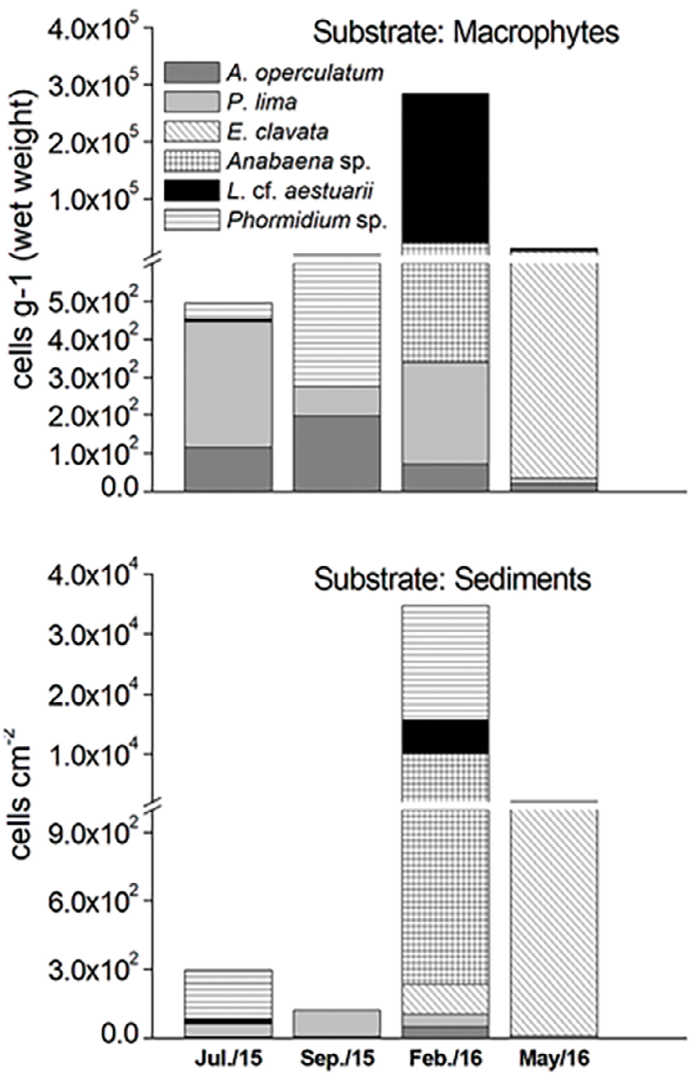

Figure 5. Spatial and temporal variation of the cell abundance among the dominant species of potentially toxic benthic microalgae collected on different substrates in the ECPB from July 2015 to May 2016.

In this large estuary, high abundance of non-toxic benthic microalgae, in especial diatoms, should therefore support high secondary productivity by benthic consumers like bivalves, crabs, fish, gastropods, isopods and polychaetes (Choy et al., 2008), as well as pelagic consumers (e.g. zooplankton) via resuspension of benthic microalgae into the water column (Modéran et al., 2012). In contrast, sediments and macrophytes from the ECPB sheltered a relatively low species richness and abundance of benthic dinoflagellates compared to that of marine environments from different parts of the globe, including other Brazilian regions (Nascimento et al., 2012, 2016; Chomérat et al., 2018). These findings agree with previous reports for other brackish water-dominated estuaries, where heavier freshwater inflows tend to favor diatoms, cyanobacteria and green algae to the detriment of dinoflagellates (Fonseca et al., 2013; Maggi et al., 2017).
The results described in this study provide a first glance at the temporal variability in diversity and abundance of potentially toxic MPB taxa occurring in this large and ecologically relevant subtropical estuary. Local assemblages of potentially toxic MPB were dominated by low densities of dinoflagellates in winter (July-September), and by high densities of cyanobacteria in summer (February). The dominant cyanobacteria, mainly L. cf. aestuarii, exhibited high abundance in February and were correlated with heavier rainfall, lower salinity and higher turbidity (shallower Secchi depths) typical of summer in this subtropical area. In fact, cyanobacteria can tolerate wide and abrupt changes in salinity and temperature, and are able to survive under low light conditions (Paerl et al., 2000). This provides a competitive advantage in estuarine environments subjected to intense discharge of freshwater and the associated high loads of particles in suspension, as observed under regular summer conditions in the ECPB (Lana et al., 2001; Funari and Testai, 2008). Nevertheless, no other study has previously focused on benthic cyanobacteria in the ECPB area to support the temporal pattern indicated herein.

When favorable conditions prevail, such as high temperature, high $\mathrm{pH}$, and increased availability of nutrients, especially those artificially released by anthropogenic activities (Chorus and Bartram, 1999), cyanobacteria can form superficial blooms in estuaries. Mostly in summer, the ECPB receives intense continental and urban discharges from extensive drainage basins, retaining sediments, nutrients, organic compounds, heavy metals and other contaminants (Choueri et al., 2009; Cabral et al., 2018). Although the concentrations of nutrients, as determined in the water column adjacent to the sampling sites, were not as high throughout the present study, moderate concentrations of dissolved inorganic nitrogen such as ammonium were recorded in February. Furthermore, concentrations of inorganic phosphorus and nitrogen in the ECPB, including those measured in shallow areas of intertidal flats and in the sediments, are often higher than those measured in the present study (e.g., Mafra Junior et al., 2006; Fonseca et al., 2013).

Contrary to cyanobacteria, the development of benthic dinoflagellates - and their preferred host macrophytes - requires periods of greater 

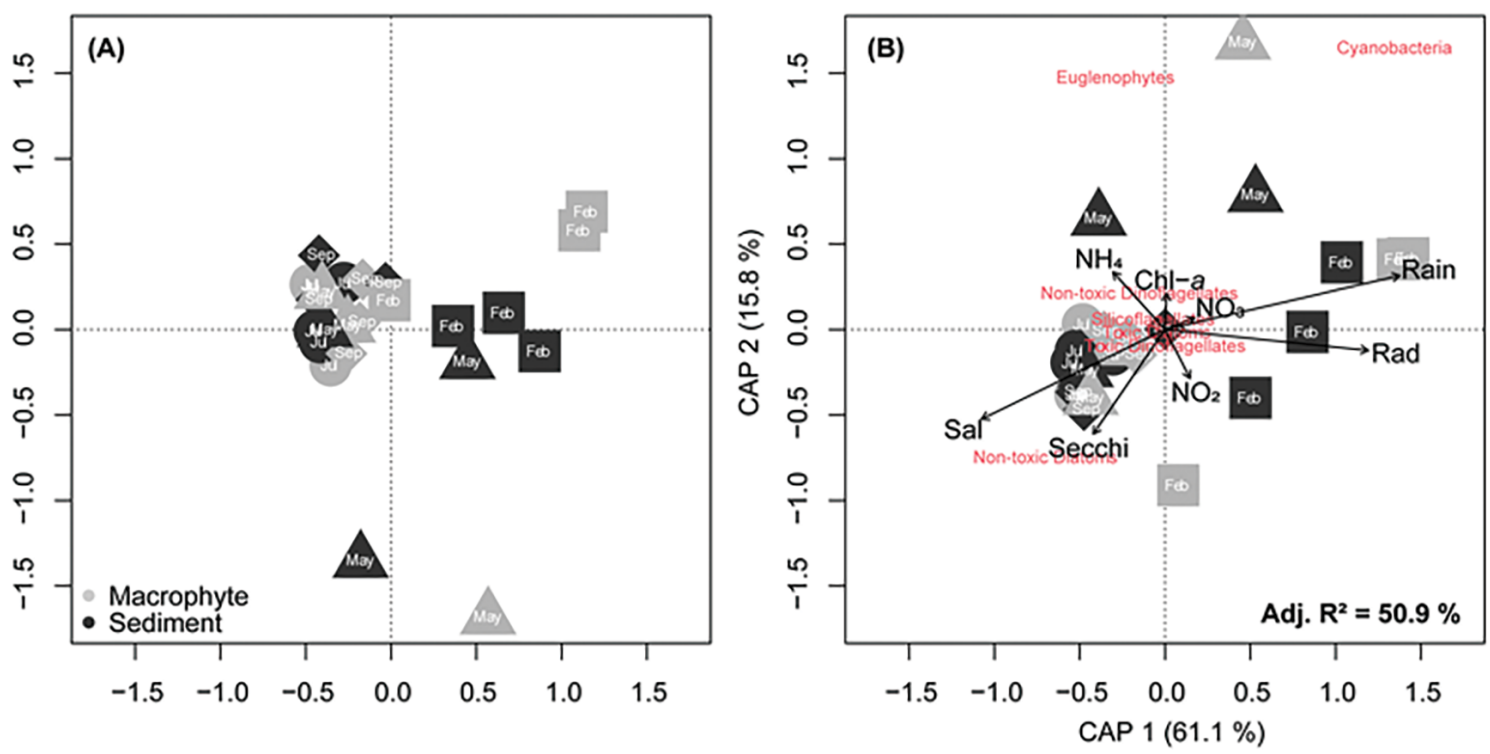

Figure 6. Constrained and unconstrained multidimensional ordination of the Bray-Curtis dissimilarities in overall microphytobenthic asseamblage across substrates and time (sampling months). (A) Unconstrained non-metric multidimensional ordination n-MDS; (B) Constrained analysis of principal coordinates CAP - arrows' length is proportional to the variation in community explained by the environmental variables; Macrophytes in light gray, Sediment in dark gray.
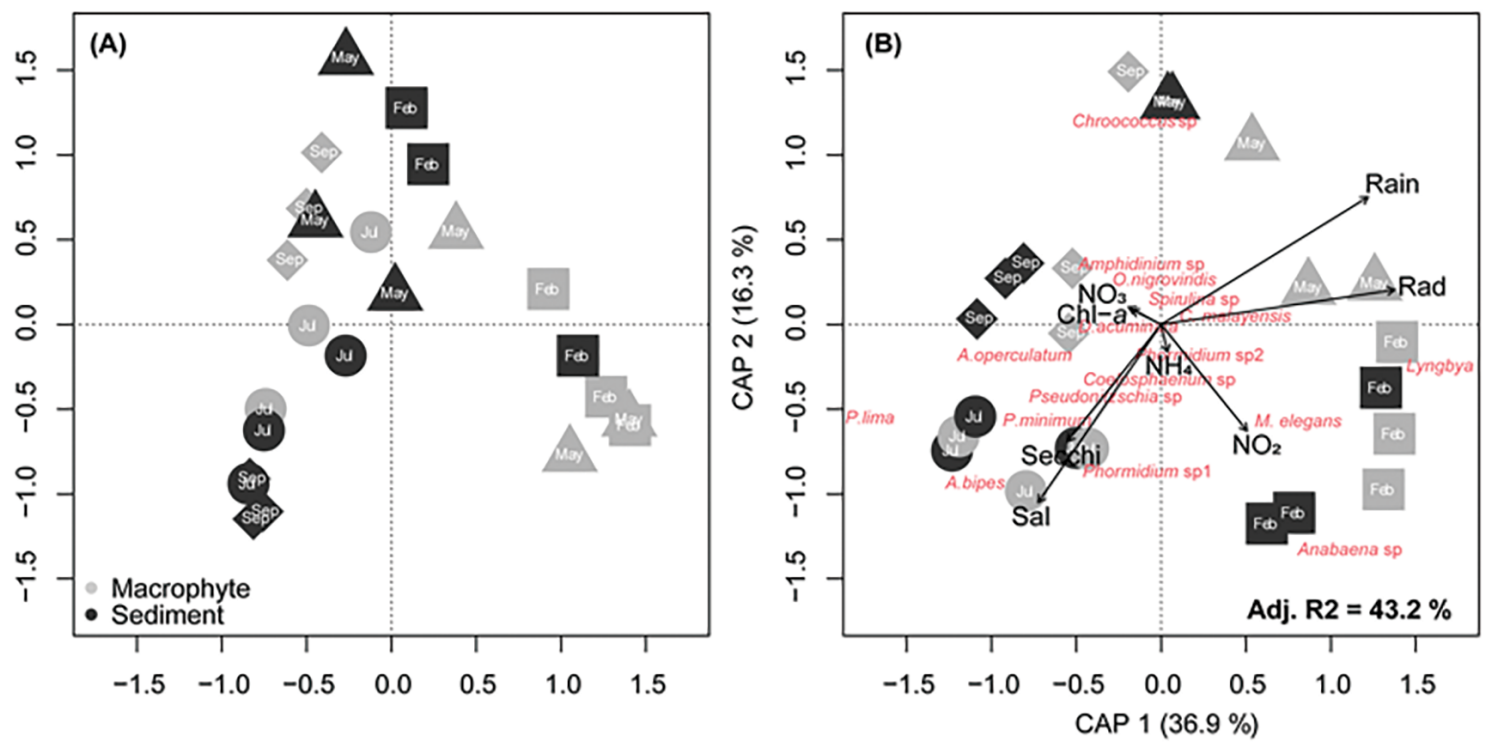

Figure 7. Constrained and unconstrained multidimensional ordination of the Bray-Curtis dissimilarities in potentially toxic microalgae across across substrates and time (sampling months). (A) Unconstrained non-metric multidimensional ordination n-MDS; (B) Constrained analysis of principal coordinates CAP - arrows'length is proportional to the variation in community explained by the environmental variables; Macrophytes in light gray, Sediment in dark gray. Only the most abundant species are shown (i.e., those contributing to $70 \%$ of the total relative abundance).

hydrological stability (Vila et al., 2001). Overall, benthic dinoflagellates are more abundant under relatively stable water column conditions, which reduce losses due to turbulence and runoff (Vila et al., 2001;
Richlen and Lobel, 2011). Likewise, the highest cell abundances of various dinoflagellates, including the potentially toxic species Prorocentrum cf. lima and Amphidinium operculatum, were recorded on 
opportunistic green macroalgae (Ulva spp.) blooming mainly in the most sheltered sampling sites of the ECPB in July. During this drier period, higher water transparency, lower runoff contribution and higher salinity acan all stimulate the growth of dinoflagellates inside the estuary.

Moderate abundances of $P$. cf. lima, however, were also registered in February, during summer. At that time, cells were sampled from mats dominated by the benthic filamentous cyanobacterium L. cf. aestuarii, confirming the importance of macrophytic substrates for benthic dinoflagellates. Moreover, these findings also indicate that the low salinities (19-28) recorded during that time in the ECPB did not affect the development of $P$. cf. lima over the study area, in accordance to laboratory experiments showing that a local toxigenic strain of $P$. cf. lima was tolerant to abrupt salinity changes (Sobrinho and Mafra, 2016). Therefore, besides occurring throughout the year, it is plausible to assume that $P$. cf. lima inhabits an even larger estuarine area than that covered by the present study, increasing the risk for toxin transfer across the benthic food webs.

Prorocentrum cf. lima was the most frequent and abundant toxic dinoflagellate in this study. This species is widely distributed in both temperate and tropical waters, and can be an important source of the diarrhetic toxins okadaic acid (OA) and dinophysistoxins (DTXs) in coastal environments (Foden et al., 2005). A P. cf. lima strain isolated from the ECPB has been recently shown to produce moderate concentrations of both OA and DTX-1 (MoreiraGonzález et al., 2018), indicating that the species could be thus an important source of toxins to the benthic food web in this region. The average cell densities of $P$. cf. lima found on macrophytes (up to

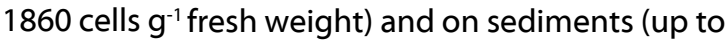
320 cells $\mathrm{cm}^{-2}$ ) in the present study are within the range reported for this species in other coastal areas worldwide (Nascimento et al., 2005; Maranda et al., 2007; Takahashi et al., 2008). In fact, cells of $P$. lima complex were previously recorded (as Prorocentrum sp.) at even higher cell abundances (up to 3570 cells $\mathrm{cm}^{-2}$ ) in sediment samples from the ECPB (Brustolin et al., 2014). Prorocentrum sp. was another benthic dinoflagellate found on sediment (up to 301 cells $\mathrm{cm}^{-2}$ ) and macrophytes (up to 601 cells $\mathrm{g}^{-1}$ ) in the present study. One specimen was isolated and cultured in parallel to this study. Toxicological examination of concentrated Prorocentrum sp. extracts indicated high acute toxicity to mice, even though no diarrheic toxins have been detected in the same strain (Moreira-González et al., 2019).

Benthic dinoflagellates have proved to be important sources of marine toxins. Most potentially toxic species of benthic dinoflagellates found in the present study (e.g., P. cf. lima, A. operculatum and Coolia malayensis) are frequently reported over a broad range of different marine ecosystems worldwide, and may produce a wide variety of toxic compounds (Berdalet et al., 2017). Some strains of Amphidinium spp., including A. operculatum, produce compounds with hemolytic and antifungal properties (amphidinols and amphidinolides), which are potentially toxic to fish (Yasumoto et al., 1987; Espiritu et al., 2017). Similarly, Coolia spp. can also elicit cytotoxic and hemolytic effects, as shown by in vitro bioassays (Karafas et al., 2015; Leaw et al., 2016). Although there is no report of toxic effects on humans associated with Coolia, toxicological effects have been observed in mice (Paz et al., 2008; Korsnes et al., 2014; Karafas et al., 2015; MoreiraGonzález et al., 2019). Potentially causative compounds may include the cooliatoxins, a yessotoxin analog first described in some strains of Coolia tropicalis Faust (Holmes et al., 1995). Recently, five yessotoxin analogs were chemically characterized from C. malayensis from Okinawa, Japan (Wakeman et al., 2015). In addition to dinoflagellates, some euglenophytes including Euglenaria clavata, which occurred in summer-autumn at moderate cell abundance in the ECPB, have been found to produce euglenophycin, a toxin associated with ichthyotoxic effects (i.e., fish kills) (Zimba et al., 2017).

Like in other large estuaries [e.g. Chesapeake Bay, USA (Semcheski et al., 2016)], both diversity and abundance of potentially toxic cyanobacteria in the ECPB were much higher than that of dinoflagellates and euglenophytes. Most cyanobacterial genera found in this study (Anabaena, Calothrix, Chroococcus, Coelosphaerium, Lyngbya, Merismopedia, Oscillatoria and Phormidium) are known to produce compounds with hepatotoxic activity (cyanotoxins), being microcystins the most common of them (Carmichael, 2001; Pearson et al., 
2010). In addition, some of these brackish-water cyanobacterial genera can produce other potent neurotoxins, including anatoxins (from Anabaena, Oscillatoria and Phormidium), saxitoxins (Anabaena and Lyngbya) and antillatoxin (Lyngbya) (Pearson et al., 2010). A group of estuarine species (e.g. Lyngbya and Oscillatoria spp.) is also capable of producing dermatotoxins such as lyngbyatoxins and aplysiatoxins. Recently, the toxin b-N-methylamino-Lalanine (BMAA) and different novel cytotoxic and apoptosis-inducing compounds have been described from several marine cyanobacteria, including benthic species (Monteiro et al., 2017). Exposure to BMAA has been associated with an increased risk of neurodegenerative diseases such as amyotrophic lateral sclerosis, Parkinson's and Alzheimer's diseases (Bradley et al., 2013). Finally, benthic cyanobacteria belonging to the genera Hydrocoleum, Phormidium, Oscillatoria and Anabaena have been linked to acute food poisoning with similar symptoms to those characteristic of ciguatera in New Caledonia, French Polynesia, and Vanuatu, Pacific Ocean (Laurent et al., 2012). Benthic-feeding organisms may be thus exposed to a variety of toxic compounds in the ECPB as cyanobacteria were not only diverse, but also frequent and sometimes very abundant over the investigated period.

The mat-forming $L$. cf. aestuarii was extremely abundant during February, the warmest month, attaining $5.0 \times 10^{4}$ cells $\mathrm{cm}^{-2}$ on the sediments and $1.4 \times 10^{6}$ cells $\mathrm{g}^{-1}$ on macrophytes. Even thought this marine/estuarine cyanobacterium is not known to produce the potent lyngbyatoxins, other cytotoxic compounds have been isolated from this species (Mclntosh et al., 2013). In fact, the present study reported, additionally, acute toxicity to nauplii of the brine shrimp $A$. salina elicited by an aqueous extract from $L$. cf. aestuarii-dominated mats, as previously reported for strains of other estuarine, benthic filamentous cyanobacteria genera such as Leptolyngbya, Microcoleus, Nodularia, Nostoc and Phormidium (Lopes et al., 2010). However, low abundances of other potentially toxic cyanobacteria such as Anabaena sp., Calothrix crustacea, Phormidium spp., Oscillatoria nigroviridis and the toxic dinoflagellate $P$. cf. lima were found associated with these mats in our study, so that the observed toxicity may not be attributed to
L. cf. aestuarii per se, but rather to a toxic benthic microbial corsortium. On a different perspective, bioactive compounds from benthic microalgae may possess potential therapeutic activity against pathogenic agents (e.g. viruses, bacteria, fungi) and several diseases including cancer (Tan, 2010; Zimba et al., 2016; Espiritu et al., 2017).

Besides the benthic microalgae, four species of potentially harmful planktic microalgae were also reported in this study occurring sporadically on the sampled substrates: the dinoflagellates Prorocentrum minimum and Dinophysis cf. acuminata, the diatom Pseudo-nitzschia sp. and the cyanobacterium Coelosphaerium sp. Most $P$. minimum strains investigated so far were harmless, but some of them seemed to produce neurotoxic compounds that rapidly killed mice when injected intraperitoneally (Grzebyk et al., 1997), and exhibited acute toxicity to mollusks larvae and Artemia nauplii (Wickfors and Smolowitz, 1995). Similarly, among several strains of Pseudo-nitzschia spp. isolated from southern Brazil, including in the ECPB area, the amnesic toxin domoic acid was only detected at low levels in two species, $P$. calliantha and $P$. cf. multiseries (Wadt et al., 2017). Moreover, both P. minimum and Pseudo-nitzschia sp. were found at very low cell densities and only within the MPB collected in one or two out of four sampled dates. Finally, D. cf. acuminata, species complex responsible for the vast majority of DSP cases worldwide (see Kamiyama and Suzuki, 2009; Reguera et al., 2012), only appeared at one occasion and at very low cell abundances in our benthic samples. In contrast, Dinophysis spp. can be frequently found in plankton samples (Mafra et al., 2006, 2014) and is commonly associated with the contamination of filter-feeding organisms in the outer sector of the ECPB and adjacent continental shelf (Mafra et al., 2014, 2019). Therefore, transfer of toxic Dinophysis cells - and their toxins - from the water column to the benthos can be eventually much more significant than that reported during the present investigation. Indeed, only two months after the sampling period covered by this study, transfer of OA to benthic-feeders (e.g. bivalve mollusks, the ghost shrimp Callichirus major and the sand dollar Mellita quinquiesperforata) has been reported during a massive $D$. cf. acuminata bloom in this region (Mafra et al., 2019). 


\section{CONCLUSION}

This work confirms the importance of benthic microalgae as primary producers in mud-sand flats of this large, tide-driven estuarine system, where mangrove and phytoplankton producers have received much more attention in past studies on ecosystem ecology. Moreover, our investigation has indicated that, at certain occasions, benthic algae are not only important sources of energy but also of toxic compounds to benthic food webs in this area. Potentially toxic microalgae were represented within different MPB taxonomic groups (cyanobacteria, dinoflagellates, euglenophytes and diatoms) in this subtropical estuarine system. Despite the dominance of non-toxic diatoms in terms of richness and abundance, the mat-forming Lyngbya cf. aestuarii and other dominant cyanobacteria were very abundant in February, during austral summer, strongly associated with higher rainfall. Contrarily, dinoflagellates, including the toxic species Amphidinium operculatum and Prorocentrum cf. lima, were relatively dominant in drier months characterized by lower water turbulence (July and September). These findings are very relevant for artisanal fisheries and aquaculture - important regional economical activities and a food security issue in this low-income region - as well as for conservation actions towards key species that use this ecosystem as nursery and feeding area, such as mollusks, crustaceans, fish and the endangered sea turtle Chelonia mydas. The occurrence of toxic benthic microalgal species in the ECPB, which had been vastly underestimated so far, should be therefore considered in future studies and actions addressing the risks for environmental and human health in this region.

\section{ACKNOWLEDGEMENTS}

This study was supported by the International Atomic Energy Agency (IAEA) through the Research Contract \#18827 (CRP K41014). The authors are most grateful to CAPES and CNPq (Brazil) for the Ph.D. scholarship awarded to A.R.M.G. through the co-funded PEC-PG Program, to Fundação Araucária (Brazil) for the grant awarded to L.L.M., as well as to Ligia F. G. da Luz (Universidade Federal do Paraná) for the assistance with graphic design.

\section{AUTHOR CONTRIBUTIONS}

A.R.M.-G.: Investigation; Methodology; Visualization; Writing - original draft; Writing - review \& editing. M.C.B.: Formal Analysis; Writing - review \& editing. L.L.M.Jr.: Conceptualization; Funding Acquisition; Project Administration; Resources; Supervision; Writing - review \& editing.

\section{REFERENCES}

ANDERSON, M. J. 2001. A new method for non-parametric multivariate analysis of variance. Austral Ecology, 26, 1, 32-46.

ANDERSON, M. J. \& ROBINSON, J. 2003. Generalized discriminant analysis based on distances. Australian \& New Zealand Journal of Statistics, 45, 301-318.

ANDERSON, M. J. \& WILLIS, T. J. 2003. Canonical analysis of principal coordinates: a useful method of constrained ordination for ecology. Ecology, 84, 2, 511-525.

BERDALET, E., TESTER, P. A., CHINAIN, M., FRAGA, S., LEMEE, R., LITAKER, W. \& ZINGONE, A. 2017. Harmful algal blooms in benthic systems: recent progress and future research. Oceanography, 30, 1, 36-45.

BRADLEY, W. G., BORENSTEIN, A. R., NELSON, L. M., CODD, G. A., ROSEN, B. H., STOMMEL, E. W. \& COX, P. A. 2013. Is exposure to cyanobacteria an environmental risk factor for amyotrophic lateral sclerosis and other neurodegenerative diseases? Amyotrophic Lateral Sclerosis \& Frontotemporal Degeneration, 14, 5-6, 325-333.

BRUSTOLIN, M. C., THOMAS, M. C., MAFRA JUNIOR, L. L. \& LANA, P. C. 2014. Does Encope emarginata (Echinodermata: Echinoidea) affect spatial variation patterns of estuarine subtidal meiofauna and microphytobenthos? Journal of Sea Research, 91, 70-78.

BRUSTOLIN, M. C., THOMAS, M. C., MAFRA JUNIOR, L. L. \& LANA, P. C. 2016. Bioturbation by the sand dollar Encope emarginata (Echinoidea, Mellitidae) changes the composition and size structure of microphytobenthic assemblages. $\mathrm{Hy}$ drobiologia, 779, 1, 183-192.

CABRAL, A. C., STARK, J. S., KOLM, H. E. \& MARTINS, C. C. 2018. An integrated evaluation of some faecal indicator bacteria (FIB) and chemical markers as potential tools for monitoring sewage contamination in subtropical estuaries. Environmental Pollution, 235, 739-749.

CAMARGO, M. G. 2006. SysGran: um sistema de código aberto para análises granulométricas do sedimento. Revista Brasileira de Geociências, 36, 2, 371-378.

CARMICHAEL, W. W. 2001. Health effects of toxin-producing cyanobacteria: "The CyanoHABs". Human and Ecological Risk Assessment, 7, 5, 1393-1407.

CHOMÉRAT, N., BILIEN, G. \& ZENTZ, F. 2018. A taxonomical study of benthic Prorocentrum species (Prorocentrales, Dinophyceae) from Anse Dufour (Martinique Island, eastern Caribbean Sea). Marine Biodiversity, 49, 1299-1319.

CHORUS, I. \& BARTRAM, J. 1999. Toxic Cyanobacteria in water: a guide for their public health consequences, monitoring and management, London, E \& FN Spon.

CHOUERI, R. B., CESAR, A., TORRES, R. J., ABESSA, D. M., MORAIS, R. D., PEREIRA, C. D., NASCIMENTO, M. R., MOZETO, A. A., 
RIBA, I. \& DELVALLS, T. A. 2009. Integrated sediment quality assessment in Paranaguá Estuarine System, southern Brazil. Ecotoxicology and Environmental Safety, 72, 7, 1824-1831.

CHOY, E. J., AN, S. \& KANG, C. K. 2008. Pathways of organic matter through food webs of diverse habitats in the regulated Nakdong River estuary (Korea). Estuarine, Coastal and Shelf Science, 78, 1, 215-226.

CRISPINO, L. M. B. \& SANT'ANNA, C. L. 2006. Cianobactérias marinhas bênticas de ilhas costeiras do Estado de São Paulo, Brasil. Revista Brasileira de Botânica, 29, 4, 45-56.

ESPIRITU, R. A., TAN, M. C. S. \& OYONG, G. G. 2017. Evaluation of the anti-cancer potential of Amphidinol 2, a polyketide metabolite from the marine dinoflagellate Amphidinium klebsii. Jordan Journal of Biological Sciences, 10, 297-302.

FONSECA, A. L. D. O., MACHADO, E. D. C., BRANDINI, F. P., \& BRANDINI, N. 2013. Microphytobenthic biomass on a subtropical intertidal flat of Paranagua Bay (Southern Brazil): spatio-temporal distribution and the influence of environmental conditions. Brazilian Journal of Oceanography, 61, 2, 83-92.

FODEN, J., PURDIE, D. A., MORRIS, S. \& NASCIMENTO, S. 2005. Epiphytic abundance and toxicity of Prorocentrum lima populations in the Fleet Lagoon, UK. Harmful Algae, 4, 6, 1063-1074.

FUNARI, E. \& TESTAI, E. 2008. Human health risk assessment related to cyanotoxins exposure. Critical Reviews in Toxicology, $38,2,97-125$.

GRASSHOFF, K., EHRHARDT, M. \& KREMLING, K. 1983. Methods of seawater analysis, $2^{\text {a }}$ ed., Weinheim, Verlag Chemie.

GRZEBYK, D., DENARDOU, A., BERLAND, B. \& POUCHUS, Y. F. 1997. Evidence of a new toxin in the red-tide dinoflagellate Prorocentrum minimum. Journal of Plankton Research, 19, 8, 1111-1124.

HALLEGRAEFF, G. M., ANDERSON, D. M. \& CEMBELLA, A. D. 2003. Manual on harmful marine microalgae, France, UNESCO Publishing.

HOLMES, M. J., LEWIS, J. L., JONES, A. \& WONG, H. A. W. 1995. Cooliatoxin, the first toxin from Coolia monotis (Dinophyceae). Natural Toxins, 3, 5, 355-362.

HOPPENRATH, M., CHOMÉRAT, N., HORIGUCHI, T., SCHEIKERT, M., NAGAHAMA, Y. \& MURRAY, S. 2013. Taxonomy and phylogeny of the benthic Prorocentrum species (Dinophyceae)-A proposal and review. Harmful Algae, 27, 1-28.

HOPPENRATH, M., MURRAY, S. A., CHOMÉRAT, N. \& HORIGU$\mathrm{CHI}, \mathrm{T}$. 2014. Marine benthic dinoflagellates - unveiling their worldwide biodiversity, Germany, Kleine Senckenberg-Reihe Publishing.

KAMIYAMA, T. \& SUZUKI, T. 2009. Production of dinophysistoxin-1 and pectenotoxin-2 by a culture of Dinophysis acuminata (Dinophyceae). Harmful Algae, 8, 2, 312-317.

KARAFAS, S., YORK, R. \& TOMAS, C. 2015. Morphological and genetic analysis of the Coolia monotis species complex with the introduction of two new species, Coolia santacroce sp. nov. and Coolia palmyrensis sp. nov. (Dinophyceae). Harmful Algae, 46, 18-33.

KORSNES, M. S., RØED, S. S., TRANULIS, M. A., ESPENES, A. \& CHRISTOPHERSEN, B. 2014. Yessotoxin triggers ribotoxic stress. Toxicology in Vitro, 28, 5, 975-981.

LANA, P. C., MARONE, E., LOPES, R. M. \& MACHADO, E. C. 2001. The subtropical estuarine complex of Paranaguá Bay, Brazil. In: SELLIGER, U., KJERFVE, P., (eds.), Coastal marine ecosystems of Latin America. Berlin: Springer-Verlag.
LASSUS, P., CHOMERAT, N., HESS, P. \& NEZAN, E. 2016. Toxic and harmful microalgae of the World Ocean. Micro-algues toxiques et nuisibles de l'Océan Mondial. IOC Manuals and guides, 68 (Bilingual English/French). Denmark: International Society for the Study of Harmful Algae/Intergovernmental Oceanographic Commission of UNESCO.

LAURENT, D. KERBRAT, A. S., DARIUS, H. T., ROSSI, F., YEETING, B., HADDAD, M., GOLUBIC, S., PAUILLAC, S. \& CHINAIN, M. 2012. Ciguatera shellfish poisoning (CSP): a new ecotoxicological phenomenon from cyanobacteria to humans via giant clams. In: JENSEN, M. A., MULLER, D. W., (eds.), Food Chain: New Research. New York: Nova Science Publishers.

LEAW, C. P., TAN, T. H., LIM, H. C., TENG, S. T., YONG, H. L., SMITH, K. F., RHODES, L., WOLF, M., HOLLAND, W. C., VANDERSEA, M. W., LITAKER, R. W., TESTER, P. A., GU, H., USUP, G., LIM, P.T. 2016. New scenario for speciation in the benthic dinoflagellate genus $\mathrm{CoO}$ lia (Dinophyceae). Harmful Algae, 55, 137-149.

LOPES, V. R., FERNÁNDEZ, N., MARTINS, R. F. \& VASCONCELOS, V. 2010. Primary screening of the bioactivity of brackish water cyanobacteria: Toxicity of crude extracts to Artemia salina larvae and Paracentrotus lividus embryos. Marine Drugs, 8 , 3, 471-482.

LOPES, V. R. \& VASCONCELOS, V. M. 2011. Planktonic and benthic cyanobacteria of European brackish waters: a perspective on estuaries and brackish seas. European Journal of Phycology, 46, 3, 292-304.

MAFRA JUNIOR, L. L., FERNANDES, L. F. \& PROENÇA, L. A. O. 2006. Harmful algae and toxins in Paranaguá bay, Brazil: bases for monitoring. Brazilian Journal of Oceanography, 54, 1-2, 107-121.

MAFRA JUNIOR, L. L., TAVARES, C. P. S. \& SCHRAMM, M. A. 2014. Diarrheic toxins in field-sampled and cultivated Dinophysis spp cells from southern Brazil. Journal of Applied Phycology, 26, 4, 1727-1739.

MAFRA JUNIOR, L. L., NOLLI, P. K. W., MOTA, L. E., DOMIT, C., SOETH, M., LUZ, L. F. G., SOBRINHO, B. F., LEAL, J. G. \& DI DOMENICO, M. 2019. Multi-species okadaic acid contamination and human poisoning during a massive bloom of Dinophysis acuminata complex in southern Brazil. Harmful Algae, 89, 101662.

MAGGI, E., RINDI, L., DAL BELLO, M., FONTANINI, D., CAPOCCHI, A., BONGIORNI, L. \& BENEDETTI-CECCHI, L. 2017. Spatiotemporal variability in Mediterranean rocky shore microphytobenthos. Marine Ecology Progress Series, 575, 17-29.

MARANDA, L., CORWIN, S. \& HARGRAVES, P. E. 2007. Prorocentrum lima (Dinophyceae) in northeastern USA coastal waters. I. Abundance and distribution. Harmful Algae, 6, 623631.

MARONE, E., MACHADO, E. C., LOPES, R. M. \& SILVA, E. T. 2005. Land-ocean fluxes in the Paranaguá Estuarine System southern Brazil. Brazilian Journal of Oceanography, 53, 3-4, 169-181.

MCINTOSH, J. A., LIN, Z., TIANERO, M. D. \& SCHMIDT, E. W. 2013. Aestuaramides, a natural library of cyanobactin cyclic peptides resulting from isoprene-derived Claisen rearrangements. ACS Chemical Biology, 8, 5, 877-883.

MIZERKOWSKI, B. D., HESSE, K. J., LADWIG, N., MACHADO, E. C., ROSA, R., ARAUJO, T. \& KOCH, D. 2012. Sources, loads and dispersion of dissolved inorganic nutrients in Paranaguá Bay. Ocean Dynamics, 62, 1409-1424.

MODÉRAN, J., DAVID, V., BOUVAIS, P., RICHARD, P. \& FICHET D. 2012. Organic matter exploitation in a highly turbid en- 
vironment: Planktonic food web in the Charente estuary, France. Estuarine, Coastal and Shelf Science, 98, 126-137.

MOESTRUP, $\varnothing .$, AKSELMAN, R., CRONBERG, G., ELBRAECHTER, M., FRAGA, S., HALIM, Y., HANSEN, G., HOPPENRATH, M., LARSEN, J., LUNDHOLM, N., NGUYEN L. N. \& ZINGONE, A. 2009. IOC-UNESCO taxonomic reference list of harmful micro algae, viewed 01 Feb 2018, <http://www.marinespecies.org/hab>

MONCER, M., HAMZA, A., FEKI-SAHNOUN, W., MABROUK, L. \& HASSEN, M. B. 2017. Variability patterns of epibenthic microalgae in eastern Tunisian coasts. Scientia Marina, 81, 4, 487-498.

MONTEIRO, M., COSTA, M., MOREIRA, C., VASCONCELOS, V. M. \& BAPTISTA, M. S. 2017. Screening of BMAA-producing cyanobacteria in cultured isolates and in situ blooms. Journal of Applied Phycology, 29, 2, 879-888.

MOREIRA-GONZÁLEZ, A. R., FERNANDES, L. F., UCHIDA, H., UESUGI, A., SUZUKI, T., CHOMÉRAT, N. \& MAFRA JUNIOR, L. L. 2018. Variations in morphology, growth, and toxicity among strains of the Prorocentrum lima species complex isolated from Cuba and Brazil. Journal of Applied Phycology, $31,1,519-532$.

MOREIRA-GONZÁLEZ, A. R., FERNANDES, L. F., UCHIDA, H., UESUGI, A., SUZUKI, T., CHOMÉRAT, N., BILIEN, G., PEREIRA, T. A. \& MAFRA JUNIOR, L. L. 2019. Morphology, growth, toxin production, and toxicity of cultured marine benthic dinoflagellates from Brazil and Cuba. Journal of Applied Phycology, 31, 6, 3699-3719.

MURRAY, S. A., KOHLI, G. S., FARRELL, H., SPIERS, Z. B., PLACE, A. R., DORANTES-ARANDA, J. J. \& RUSZCZYK, J. 2015. A fish kill associated with a bloom of Amphidinium carterae in a coastal lagoon in Sydney, Australia. Harmful Algae, 49, 19-28.

NASCIMENTO, S. M., PURDIE, D. A. \& MORRIS, S. 2005. Morphology, toxin composition and pigment content of Prorocentrum lima strains isolated from a coastal lagoon in southern UK. Toxicon, 45, 5, 633-649.

NASCIMENTO, S. M., CORRÊA, E. V., MENEZES, M., VARELA, D., PAREDES, J. \& MORRIS, S. 2012. Growth and toxin profile of Ostreopsis cf. ovata (Dinophyta) from Rio de Janeiro, Brazil. Harmful Algae, 13, 1-9.

NASCIMENTO, S. M., SALGUEIRO, F., MENEZES, M., OLIVEIRA, F., MAGALHÃES, V. C. P., DE PAULA J. C \& MORRIS, S. 2016. Prorocentrum lima from the South Atlantic: morphological, molecular and toxicological characterization. Harmful Algae, 57, Pt A, 39-48.

OKSANEN, J., BLANCHET, F. G., KINDT, R., LEGENDRE, P., O'HARA, R. B., SIMPSON, G. L., SOLYMOS, P., STEVENS, M. H. H. \& WAGNER, H. 2016. Vegan: Community Ecology Package. R package version 1.17-7, viewed on October 12 2018, <http://CRAN.R-project.org/package=vegan $>$.

ORVAIN, F., LEFEBVRE, S., MONTEPINI, J., SÉBIRE, M., GANGNERY, A. \& SYLVAND, B. 2012. Spatial and temporal interaction between sediment and microphytobenthos in a temperate estuarine macro-intertidal bay. Marine Ecology Progress Series, 458, 53-68.

PAERL H. W. \& HUISMAN, J. 2009. Climate change: a catalyst for global expansion of harmful cyanobacterial blooms. Environmental Microbiology Reports, 1, 1, 27-37.

PAERL, H. W., PINCKNEY, J. L., \& STEPPE, T. F. 2000. Cyanobacterial-bacterial mat consortia: examining the functional unit of microbial survival and growth in extreme environments. Environmental Microbiology, 2, 1, 11-26.

PAZ, B., DARANAS, A. H., NORTE, M., RIOBÓ, P., FRANCO, J. M. \& FERNÁNDEZ, J. J. 2008. Yessotoxins, a group of marine polyether toxins: an overview. Marine Drugs, 6, 2, 73-102.

PEARSON, L., MIHALI, T., MOFFITT, M., KELLMANN, R. \& NEILAN, B. 2010. On the chemistry, toxicology and genetics of the cyanobacterial toxins, microcystin, nodularin, saxitoxin and cylindrospermopsin. Marine Drugs, 8, 5, 1650-1680.

QUIBLIER, C., WOOD, S., ECHENIQUE, I., HEATH, M., VILLENEUVE, A. \& HUMBERT, J. F. 2013. A review of current knowledge on toxic benthic freshwater cyanobacteria - ecology, toxin production and risk management. Water Research, 47, 5464-5479.

REGUERA, B., VELO-SUÁREZ, L., RAINE, R. \& PARK, M. G. 2012. Harmful Dinophysis species: a review. Harmful Algae, 14, 87106.

RICHLEN, M. L. \& LOBEL, P. S. 2011. Effects of depth, habitat, and water motion on the abundance and distribution of ciguatera dinoflagellates at Johnston Atoll, Pacific Ocean. Marine Ecology Progress Series, 421, 51-66.

RIEKENBERG, P. M., OAKES, J. M. \& EYRE, B. D. 2017. Uptake of dissolved organic and inorganic nitrogen in microalgae-dominated sediment: comparing dark and light in situ and ex situ additions of 15N. Marine Ecology Progress Series, 571, 29-42.

RIEKENBERG, P. M., OAKES, J. M. \& EYRE, B. D. 2018. Short-term fate of intertidal microphytobenthos carbon under enhanced nutrient availability: A13C pulse-chase experiment. Biogeosciences, 15, 2873-2889.

SEMCHESKI, M. R., EGERTON, T. A. \& MARSHALL, H. G. 2016. Composition and diversity of intertidal microphytobenthos and phytoplankton in Chesapeake Bay. Wetlands, 36, 3, 483-496.

SKINNER, M. P., LEWIS, R. J. \& MORTON, S. 2013. Ecology of the ciguatera causing dinoflagellates from the Northern Great Barrier Reef: Changes in community distribution and coastal eutrophication. Marine Pollution Bulletin, 77, 1-2, 210219.

SOBRINHO, B. F. \& MAFRA JUNIOR, L. L. 2016. 'Effects of irradiance and salinity on growth and toxin production by Prorocentrum lima', Proceedings of the 17th International Conference on Harmful Algae, 3-7 Oct 2016, Florianópolis, pp. 149.

TAKAHASHI, E. M., ARTHUR, K. E. \& SHAW, G. R. 2008. Occurrence of okadaic acid in the feeding grounds of dugongs (Dugong dugon) and green turtles (Chelonia mydas) in Moreton Bay, Australia. Harmful Algae, 7, 430-437.

TAN, L. T. 2010. Filamentous tropical marine cyanobacteria: a rich source of natural products for anticancer drug discovery. Journal of Applied Phycology, 22, 5, 659-676.

TOLHURST, T. J., GUST, G. \& PATERSON, D. M. 2002. The influence of an extracellular polymeric substance (EPS) on cohesive sediment stability. Proceedings in Marine Science, 5, 409-425.

TRAINER, V. L., ADAMS, N. G., BILL, B. D., STEHR, C. M., WEKELL, J. C., MOELLER, P., BUSMAN, M. \& WOODRUFF, D. 2000. Domoic acid production near California coastal upwelling zones, June 1998. Limnology and Oceanography, 45, 8, 1818-1833.

UNDERWOOD, G. J. C. \& KROMKAMP, J. 1999. Primary production by phytoplankton and microphytobenthos in estuaries. Advances in Ecological Research, 29, 93-153. 
VILA, M., GARCÉS, E. \& MASÓ, M. 2001. Potentially toxic epiphytic dinoflagellates assemblages on macroalgae macroalgae the NW Mediterranean. Aquatic Microbial Ecology, 26, 51-60.

WADT, P. R., MAFRA JUNIOR, L. L., TAVARES, C. P. S., FERNANDES, L. F. \& PROENÇA, L. A. O. 2017. Growth, chain formation, and toxin production by southern Brazilian Pseudo-nitzschia isolates under laboratory conditions. Environmental Monitoring and Assessment, 189, 621-635.

WAKEMAN, K. C., YAMAGUCHI, A., ROY, M. C. \& JENKE-KODAMA, H. 2015. Morphology, phylogeny and novel chemical compounds from Coolia malayensis (Dinophyceae) from Okinawa, Japan. Harmful Algae, 44, 8-19.

WICKFORS, G. H. \& SMOLOWITZ, R. M. 1995. Experimental and histological studies of four life-history stages of the Eastern
Oyster, Crassostrea virginica, exposed to a cultured strain of the dinoflagellate Prorocentrum minimum. The Biological Bulletin, 188, 3, 313-328.

YASUMOTO, T., SEINO, N., MURAKAMI, Y. \& MURATA, M. 1987. Toxins produced by benthic dinoflagellates. The Biological Bulletin, 172, 1, 128-131.

ZIMBA, P. V., HUANG, I. S., GUTIERREZ, D., SHIN, W. G, BENNETT, M. S. \& TRIEMER, R. E. 2017. Euglenophicin is produced in at least six species of euglenoid algae and six of seven strains of Euglena sanguinea. Harmful Algae, 63, 79-84.

ZIMBA, P.V., ORDNER, P. \& GUTIERREZ, D. 2016. Selective toxicity and angiogenic inhibition by euglenophycin: a role in cancer therapy? Cancer Metastasis - Biology and Treatment, 3, 8, 8 . 
SUPPLEMENTARY MATERIAL

Appendix A. List of benthic microalgae found on different substrates collected at three stations along the ECPB, their mean and maximum (between brackets) abundance [cells $\mathrm{cm}^{-2}$ for sediment (S) and cells $\mathrm{g}^{-1}$ wet weight for macrophyte $(\mathrm{M})]$, and the relative abundance (RA) values (\%). Asterisks indicate potentially toxic species.

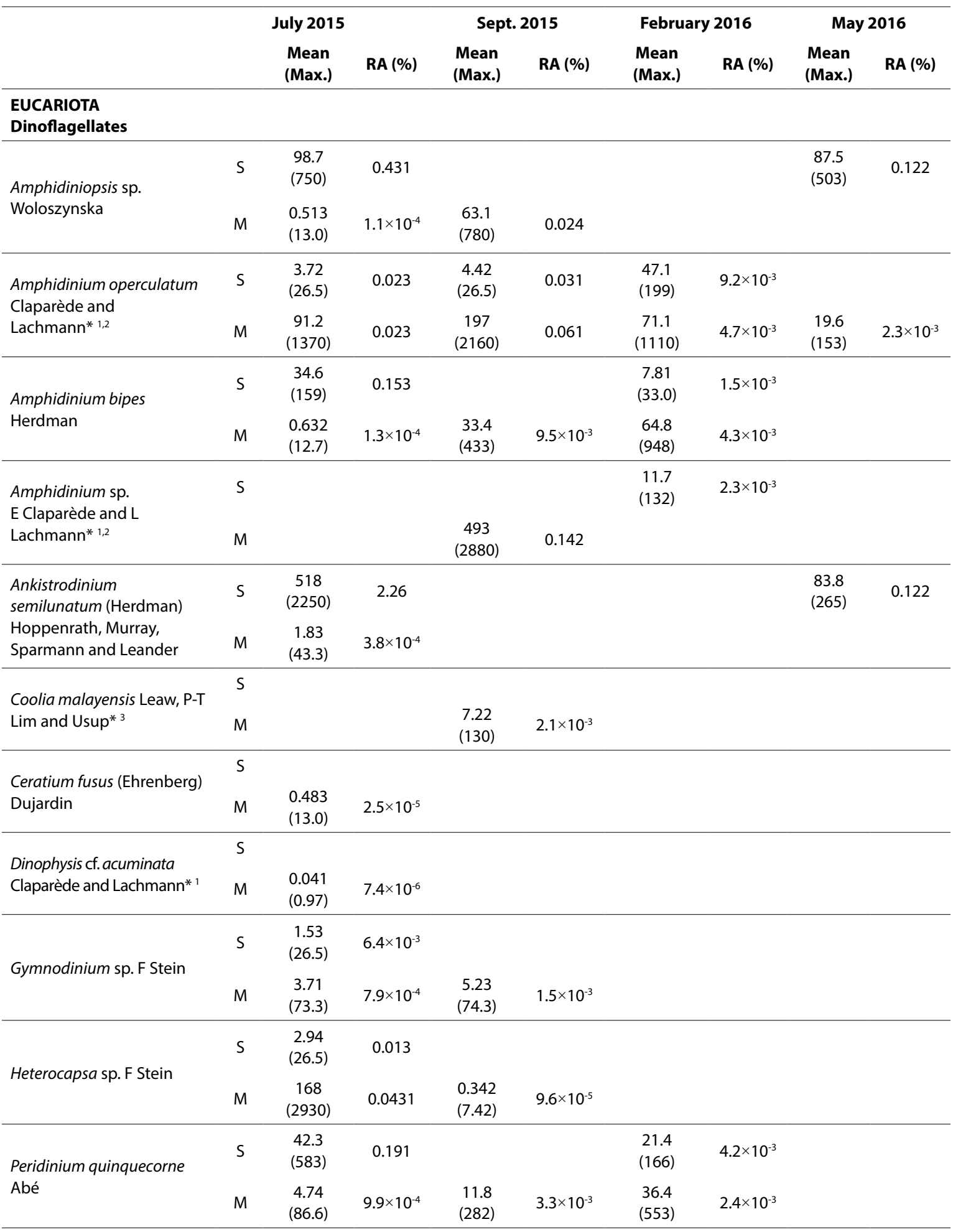




\begin{tabular}{|c|c|c|c|c|c|c|c|c|c|}
\hline \multirow{2}{*}{$\begin{array}{l}\text { Prorocentrum cf. fukuyoi S } \\
\text { Murray and Y Nagahama }\end{array}$} & $\mathrm{S}$ & $\begin{array}{c}7.34 \\
(53.0)\end{array}$ & 0.033 & $\begin{array}{c}10.3 \\
(53.0)\end{array}$ & 0.061 & $\begin{array}{c}144 \\
(530)\end{array}$ & 0.033 & $\begin{array}{l}102 \\
(344)\end{array}$ & 0.142 \\
\hline & M & $\begin{array}{c}11.0 \\
(155)\end{array}$ & $2.3 \times 10^{-3}$ & $\begin{array}{c}123 \\
(1030)\end{array}$ & 0.042 & $\begin{array}{c}145 \\
(715)\end{array}$ & $9.6 \times 10^{-3}$ & $\begin{array}{c}248 \\
(86.6) \\
\end{array}$ & 0.032 \\
\hline \multirow{2}{*}{$\begin{array}{l}\text { Prorocentrum minimum } \\
\text { (Pavillard) J. Schiller* } 1\end{array}$} & $\mathrm{~S}$ & & & & & $\begin{array}{c}19.5 \\
(331)\end{array}$ & $3.8 \times 10^{-3}$ & & \\
\hline & M & $\begin{array}{c}6.53 \\
(89.6)\end{array}$ & $1.4 \times 10^{-3}$ & & & $\begin{array}{c}1.54 \\
(54.1)\end{array}$ & $9.9 \times 10^{-5}$ & & \\
\hline \multirow{2}{*}{$\begin{array}{l}\text { Prorocentrum lima (Ehrenb.) } \\
\text { Dodge* } 1^{*}\end{array}$} & $\mathrm{~S}$ & $\begin{array}{l}57.5 \\
(361)\end{array}$ & 0.253 & $\begin{array}{c}118 \\
(331)\end{array}$ & 0.672 & $\begin{array}{l}58.7 \\
(199)\end{array}$ & 0.013 & $\begin{array}{l}7.44 \\
(26.8)\end{array}$ & 0.012 \\
\hline & M & $\begin{array}{c}192 \\
(4024)\end{array}$ & 0.043 & $\begin{array}{l}78.3 \\
(513)\end{array}$ & 0.022 & $\begin{array}{c}267 \\
(2410)\end{array}$ & 0.022 & $\begin{array}{c}14.0 \\
(86.6)\end{array}$ & $1.7 \times 10^{-3}$ \\
\hline \multirow{2}{*}{$\begin{array}{l}\text { Prorocentrum micans } \\
\text { Ehrenberg }\end{array}$} & $\mathrm{S}$ & & & & & & & & \\
\hline & M & $\begin{array}{l}0.293 \\
(10.4)\end{array}$ & $6.1 \times 10^{-5}$ & $\begin{array}{c}10.1 \\
(128)\end{array}$ & $6.7 \times 10^{-4}$ & & & & \\
\hline \multirow{2}{*}{$\begin{array}{l}\text { Prorocentrum scutellum } \\
\text { Schröder }\end{array}$} & $\mathrm{S}$ & $\begin{array}{l}2.92 \\
(53.0)\end{array}$ & 0.012 & $\begin{array}{c}1.53 \\
(26.5)\end{array}$ & $8.3 \times 10^{-3}$ & & & $\begin{array}{l}3.74 \\
(26.5)\end{array}$ & $5.2 \times 10^{-3}$ \\
\hline & M & $\begin{array}{l}0.122 \\
(4.33)\end{array}$ & $2.6 \times 10^{-5}$ & $\begin{array}{c}2.73 \\
(65.0)\end{array}$ & $7.7 \times 10^{-4}$ & $\begin{array}{c}14.3 \\
(128)\end{array}$ & $9.4 \times 10^{-4}$ & & \\
\hline \multirow{2}{*}{$\begin{array}{l}\text { Prorocentrum sp. } \\
\text { Ehrenberg* } 4\end{array}$} & $\mathrm{~S}$ & $\begin{array}{l}21.1 \\
(301)\end{array}$ & 0.091 & $\begin{array}{l}5.94 \\
(106)\end{array}$ & 0.033 & $\begin{array}{l}30.2 \\
(265)\end{array}$ & $5.9 \times 10^{-3}$ & $\begin{array}{c}8.82 \\
(53.0)\end{array}$ & 0.013 \\
\hline & M & $\begin{array}{c}19.6 \\
(130)\end{array}$ & $4.1 \times 10^{-3}$ & $\begin{array}{l}77.0 \\
(601)\end{array}$ & 0.024 & $\begin{array}{c}13.4 \\
(127)\end{array}$ & $8.8 \times 10^{-4}$ & $\begin{array}{c}10.4 \\
(81.2)\end{array}$ & $1.2 \times 10^{-3}$ \\
\hline \multirow{2}{*}{$\begin{array}{l}\text { Pyrocystis sp. Wyville- } \\
\text { Thompson }\end{array}$} & $\mathrm{S}$ & & & $\begin{array}{l}7.31 \\
(132)\end{array}$ & 0.044 & & & & \\
\hline & M & $\begin{array}{l}0.122 \\
(4.33)\end{array}$ & $2.5 \times 10^{-5}$ & & & & & & \\
\hline \multirow{2}{*}{$\begin{array}{l}\text { Sinophysis sp. D Nie and } \\
\text { C-C Wang }\end{array}$} & $\mathrm{S}$ & $\begin{array}{l}36.3 \\
(516)\end{array}$ & 0.165 & & & $\begin{array}{l}5.83 \\
(33)\end{array}$ & $1.1 \times 10^{-3}$ & & \\
\hline & M & $\begin{array}{c}1.43 \\
(48.9)\end{array}$ & $2.9 \times 10^{-4}$ & $\begin{array}{c}1.4 \\
(37.1)\end{array}$ & $4.1 \times 10^{-4}$ & $\begin{array}{c}11.0 \\
(322)\end{array}$ & $7.2 \times 10^{-4}$ & & \\
\hline \multirow[t]{2}{*}{$\begin{array}{l}\text { Togula jolla F Jørgensen, S } \\
\text { Murray and N Daugbjerg }\end{array}$} & $\mathrm{S}$ & & & & & & & $\begin{array}{l}0.123 \\
(4.34)\end{array}$ & $2.5 \times 10^{-5}$ \\
\hline & M & & & & & & & & \\
\hline \multicolumn{10}{|l|}{ Diatoms } \\
\hline \multirow{2}{*}{$\begin{array}{l}\text { Pseudo-nitzschia sp. } \mathrm{H} \\
\text { Peragallo*5,6 }\end{array}$} & $S$ & $\begin{array}{c}75.0 \\
(1350)\end{array}$ & 0.332 & & & & & & \\
\hline & M & $\begin{array}{l}1.44 \\
(52)\end{array}$ & $3.1 \times 10^{-4}$ & & & & & & \\
\hline \multirow{2}{*}{ Pennate diatoms } & $\mathrm{S}$ & $\begin{array}{c}1730 \\
(7290)\end{array}$ & 7.5 & $\begin{array}{c}16,400 \\
(36,700)\end{array}$ & 93.0 & $\begin{array}{c}449,100 \\
(1.2 \times 106)\end{array}$ & 87.7 & $\begin{array}{l}39,800 \\
(71,500)\end{array}$ & 56.4 \\
\hline & M & $\begin{array}{c}580,900 \\
\left(3.4 \times 10^{6}\right)\end{array}$ & 95.1 & $\begin{array}{c}260,600 \\
(572,000)\end{array}$ & 74.2 & $\begin{array}{c}11,900 \\
\left(1.3 \times 10^{6}\right)\end{array}$ & 83.6 & $\begin{array}{c}810,000 \\
\left(5.6 \times 10^{6}\right)\end{array}$ & 96.6 \\
\hline \multirow{2}{*}{ Centric diatoms } & $\mathrm{S}$ & $\begin{array}{c}20,000 \\
(74,100)\end{array}$ & 87.5 & $\begin{array}{c}1050 \\
(3840)\end{array}$ & 5.95 & $\begin{array}{c}18,700 \\
(30,500)\end{array}$ & 3.71 & $\begin{array}{c}27,700 \\
(92,700)\end{array}$ & 3.92 \\
\hline & M & $\begin{array}{c}23,100 \\
(445,700)\end{array}$ & 4.64 & $\begin{array}{c}85,700 \\
(234,000)\end{array}$ & 24.4 & $\begin{array}{c}16,400 \\
(97,500)\end{array}$ & 1.12 & $\begin{array}{c}15,200 \\
(71,500)\end{array}$ & 1.83 \\
\hline
\end{tabular}




\begin{tabular}{|c|c|c|c|c|c|c|c|c|c|}
\hline Euglenophytes & & & & & & & & & \\
\hline \multirow{2}{*}{$\begin{array}{l}\text { Euglenaformis proxima } \\
\text { (Dangeard) Bennett \& } \\
\text { Triemer }\end{array}$} & $\mathrm{S}$ & $\begin{array}{l}0.742 \\
(13.2)\end{array}$ & $3.2 \times 10^{-3}$ & $\begin{array}{c}1.54 \\
(26.5)\end{array}$ & $8.3 \times 10^{-3}$ & $\begin{array}{c}3.92 \\
(66.2)\end{array}$ & $7.6 \times 10^{-4}$ & & \\
\hline & M & $\begin{array}{c}574 \\
(16,500)\end{array}$ & 0.122 & $\begin{array}{c}505 \\
(7200)\end{array}$ & 0.142 & $\begin{array}{l}39.9 \\
(553)\end{array}$ & $2.6 \times 10^{-3}$ & $\begin{array}{c}134 \\
(1060)\end{array}$ & 0.022 \\
\hline \multirow{2}{*}{$\begin{array}{l}\text { Euglenaria clavata (Skuja) } \\
\text { Karnkowska and EW } \\
\text { Linton }^{* 6}\end{array}$} & $\mathrm{~S}$ & $\begin{array}{l}0.742 \\
(13.2)\end{array}$ & $3.2 \times 10^{-3}$ & & & $\begin{array}{c}138 \\
(1320)\end{array}$ & 0.033 & $\begin{array}{c}1850 \\
(5560)\end{array}$ & 2.64 \\
\hline & M & & & $\begin{array}{l}0.453 \\
(16.2)\end{array}$ & $1.3 \times 10^{-4}$ & & & $\begin{array}{c}7290 \\
(71,500)\end{array}$ & 0.923 \\
\hline \multicolumn{10}{|l|}{ Silicoflagellates } \\
\hline \multirow{2}{*}{$\begin{array}{l}\text { Dictyocha speculum } \\
\text { Ehrenberg }\end{array}$} & $\mathrm{S}$ & & & $\begin{array}{l}30.3 \\
(132)\end{array}$ & 0.174 & $\begin{array}{c}1.92 \\
(33.1)\end{array}$ & $3.8 \times 10^{-4}$ & & \\
\hline & M & $\begin{array}{c}2.02 \\
(44.8)\end{array}$ & $4.2 \times 10^{-4}$ & $\begin{array}{l}22.0 \\
(171)\end{array}$ & $6.2 \times 10^{-3}$ & & & & \\
\hline $\begin{array}{l}\text { Dictyocha octonaria } \\
\text { Ehrenberg }\end{array}$ & M & & & $\begin{array}{c}10.8 \\
(130)\end{array}$ & $3.1 \times 10^{-3}$ & & & & \\
\hline \multicolumn{10}{|l|}{$\begin{array}{l}\text { EUBACTERIA } \\
\text { Cyanobacteria }\end{array}$} \\
\hline \multirow{2}{*}{$\begin{array}{l}\text { Anabaena sp. ex Bornet } \\
\text { and Flahault }{ }^{* 7,9}\end{array}$} & $\mathrm{~S}$ & & & & & $\begin{array}{r}10, .500 \\
(53,000)\end{array}$ & 2.03 & & \\
\hline & M & $\begin{array}{c}2.32 \\
(84.4)\end{array}$ & $5.0 \times 10^{-4}$ & & & $\begin{array}{c}22,300 \\
(218,300)\end{array}$ & 1.53 & & \\
\hline \multirow{2}{*}{$\begin{array}{l}\text { Calothrix crustacea } \\
\text { C.Agardh ex Bornet and } \\
\text { Flahault }{ }^{* 7,9}\end{array}$} & $\mathrm{~S}$ & & & & & & & $\begin{array}{c}585 \\
(3180)\end{array}$ & \\
\hline & M & & & $\begin{array}{c}2640 \\
(24,100)\end{array}$ & 0.752 & & & $\begin{array}{c}423 \\
(3810)\end{array}$ & 0.052 \\
\hline \multirow{2}{*}{ Chroococcus sp. Nägeli*7 } & $\mathrm{S}$ & $\begin{array}{c}1.52 \\
(26.5)\end{array}$ & $6.4 \times 10^{-3}$ & & & $\begin{array}{c}146 \\
(530)\end{array}$ & 0.032 & $\begin{array}{l}89.8 \\
(318)\end{array}$ & 0.134 \\
\hline & M & $\begin{array}{l}33.7 \\
(898)\end{array}$ & $7.1 \times 10^{-3}$ & $\begin{array}{l}40.0 \\
(720)\end{array}$ & 0.014 & $\begin{array}{c}1150 \\
(9530)\end{array}$ & 0.083 & $\begin{array}{c}178 \\
(1300)\end{array}$ & 0.024 \\
\hline \multirow{2}{*}{ Coelosphaerium sp. Nägeli*7 } & $\mathrm{S}$ & $\begin{array}{c}1.52 \\
(26.5)\end{array}$ & $6.4 \times 10^{-3}$ & & & & & & \\
\hline & M & $\begin{array}{c}6.45 \\
(224)\end{array}$ & $1.3 \times 10^{-3}$ & $\begin{array}{c}50.1 \\
(1800)\end{array}$ & 0.015 & $\begin{array}{c}273 \\
(2060)\end{array}$ & 0.024 & & \\
\hline \multirow{2}{*}{$\begin{array}{l}\text { Lyngbya cf. aestuarii } \\
\text { (Mertens in Jürgens) } \\
\text { Liebman ex Gomont }{ }^{* 8}\end{array}$} & $\mathrm{~S}$ & $\begin{array}{c}21.6 \\
(390)\end{array}$ & 0.093 & & & $\begin{array}{c}5870 \\
(50,300)\end{array}$ & 1.14 & & \\
\hline & M & $\begin{array}{l}5.74 \\
(104)\end{array}$ & $1.2 \times 10^{-3}$ & & & $\begin{array}{c}201,300 \\
\left(1.45 \times 10^{6}\right)\end{array}$ & 13.3 & $\begin{array}{c}5120 \\
(38,350)\end{array}$ & 0.614 \\
\hline \multirow{2}{*}{ Merismopedia elegans ${ }^{* 7,9}$} & $\mathrm{~S}$ & $\begin{array}{c}1.53 \\
(13.2)\end{array}$ & $0.4 \times 10^{-3}$ & & & $\begin{array}{c}5800 \\
(50,300)\end{array}$ & 1.1 & & \\
\hline & M & & & $\begin{array}{c}60.0 \\
(891)\end{array}$ & 0.023 & $\begin{array}{c}3450 \\
(107,300)\end{array}$ & 0.233 & $\begin{array}{c}272 \\
(2000)\end{array}$ & 0.034 \\
\hline \multirow{2}{*}{$\begin{array}{l}\text { Oscillatoria nigroviridis } \\
\text { Thwaites ex Gomont }{ }^{* 7,9}\end{array}$} & $\mathrm{~S}$ & & & & & & & & \\
\hline & M & & & & & $\begin{array}{c}1070 \\
(7023)\end{array}$ & 0.11 & & \\
\hline \multirow{2}{*}{$\begin{array}{l}\text { Phormidium sp. } 1 \text { Kützing } \\
\text { ex Gomont } * 7,9\end{array}$} & $\mathrm{~S}$ & $\begin{array}{c}210 \\
(1980)\end{array}$ & 0.921 & & & $\begin{array}{c}2000 \\
(165,800)\end{array}$ & 3.92 & $\begin{array}{c}223 \\
(1340)\end{array}$ & 0.334 \\
\hline & $M$ & $\begin{array}{c}38.5 \\
(507)\end{array}$ & $7.9 \times 10^{-3}$ & $\begin{array}{c}639 \\
(5410)\end{array}$ & 0.182 & $\begin{array}{c}129 \\
(2330)\end{array}$ & $8.2 \times 10^{-3}$ & & \\
\hline
\end{tabular}




\begin{tabular}{|c|c|c|c|c|c|}
\hline \multirow{2}{*}{$\begin{array}{l}\text { Phormidium sp. } 2 \text { Kützing } \\
\text { ex Gomont*7,9 }\end{array}$} & $\mathrm{S}$ & & & $\begin{array}{c}1600 \\
(10,600)\end{array}$ & 0.313 \\
\hline & M & $\begin{array}{c}4.33 \\
(86.6)\end{array}$ & $1.2 \times 10^{-3}$ & $\begin{array}{c}3630 \\
(107,300)\end{array}$ & 0.242 \\
\hline \multirow[b]{2}{*}{ Spirulina sp. ex Gomont } & $S$ & & & & \\
\hline & M & & & $\begin{array}{c}83.6 \\
(3010)\end{array}$ & $5.5 \times 10^{-3}$ \\
\hline
\end{tabular}

References: ${ }^{1}$ Moestrup et al., 2009; ${ }^{2}$ Yasumoto et al., 1987; ${ }^{3}$ Wakeman et al., 2015; ${ }^{4}$ Moreira-González et al., $2019 ;{ }^{5}$ Trainer et al., $2000 ; 6$ Zimba et al., 2017; ${ }^{7}$ Carmichael, 2001; ${ }^{8}$ McIntosh et al., 2013; ${ }^{9}$ Lopes and Vasconcelos, 2011. 